\title{
A Comparison of Three Methods to Estimate Evapotranspiration in Two Contrasting Loblolly Pine Plantations: Age-Related Changes in Water Use and Drought Sensitivity of Evapotranspiration Components
}

\author{
Jean-Christophe Domec, Ge Sun, Asko Noormets, Michael J. Gavazzi, Emrys A. Treasure, \\ Erika Cohen, Jennifer J. Swenson, Steve G. McNulty, and John S. King
}

\begin{abstract}
Increasing variability of rainfall patterns requires detailed understanding of the pathways of water loss from ecosystems to optimize carbon uptake and management choices. In the current study we characterized the usability of three alternative methods of different rigor for quantifying stand-level evapotranspiration (ET), partitioned ET into tree transpiration $(T)$, understory transpiration, interception, and soil evaporation $\left(\mathrm{E}_{\mathrm{S}}\right)$ and determined their sensitivity to drought, and evaluated the reliability of soil moisture measurements by taking into account deep soil moisture dynamic. The analyses were conducted in an early- and in a mid-rotation stand of loblolly pine, the predominant species of southern US forest plantations. The three alternative methods for estimating ET were the eddy covariance measurements of water vapor fluxes $\left(\mathrm{ET}_{\mathrm{EC}}\right)$, the water table fluctuation $\left(\mathrm{ET}_{\mathrm{WT}}\right)$, and the soil moisture fluctuation $\left(\mathrm{ET}_{\mathrm{SM}}\right)$. On annual and monthly scales, the three methods agreed to within $10-20 \%$, whereas on a daily scale, the values of $\mathrm{ET}_{\mathrm{SM}}$ and $\mathrm{ET}_{\mathrm{EC}}$ differed by up to $50 \%$ and $\mathrm{ET}_{\mathrm{SM}}$ and $\mathrm{ET}_{\mathrm{WT}}$ differed by up to $100 \%$. The differences between the methods were attributed to root water extraction below measurement depth and to the sampling at different spatial scales. Regardless of the method used, ET at the early-rotation site was 15-30\% lower than that at the mid-rotation site. The dry years did not affect ET at the mid-rotation site but reduced significantly ET at the early-rotation site. Soil moisture trends revealed the importance of measuring water content at several depths throughout the rooting zone because less than $20 \%$ of the water is stored in the top $30 \mathrm{~cm}$ of soil. Annually, $\mathrm{E}_{\mathrm{S}}$ represented approximately 9 and $14 \%$ of $\mathrm{ET}_{\mathrm{EC}}$ at the mid-rotation site and the early-rotation site, respectively. At the mid-rotation site, $T$ accounted for approximately $70 \%$ of $\mathrm{ET}_{\mathrm{EC}}$. Canopy interception was estimated to be $5-10 \%$ of annual precipitation and $6-13 \%$ of total $\mathrm{ET}_{\mathrm{EC}}$. At the early-rotation site, $T$ accounted for only $35 \%$ of $\mathrm{ET}_{\mathrm{EC}}$. At this site, transpiration from subdominant trees and shrubs represented $40-45 \%$ of $\mathrm{ET}_{\mathrm{EC}}$, indicating that understory was a significant part of the water budget. We concluded that the eddy covariance method is best for estimating ET at the fine temporal scale (i.e., daily), but other soil moisture and water table-based methods were equally reliable and cost-effective for quantifying seasonal ET dynamics. FOR. SCI. 58(5):497-512.
\end{abstract}

Keywords: eddy covariance, loblolly pine, Pinus taeda, sapflow, soil moisture probes, water table

$\mathrm{L}$ OBLOLLY PINE (PINUS TAEDA L.) REPRESENTS ONEHALF OF THE STANDING PINE VOLUME in the southern United States (11.7 million ha) and is by far the single most commercially important forest tree species for the region, with more than 1 billion seedlings planted annually (McKeand et al. 2003). More than 1 million ha of intensively managed loblolly pine plantations are found along the lower coastal plain in eastern North Carolina. Large areas of the North Carolina coastal plain have been drained over the past 300 years, altering more than half of the total forested wetlands of that region (Campbell and Hughes 1991). Unlike upland watersheds dominated by hill slope processes, hydrologic processes on these flat and drained sites are characterized by shallow water tables that are strongly coupled with precipitation and evapotranspiration (ET) (Sun et al. 2002, 2010). For tree species, a shift in ecologic and environmental growing conditions may result in a decline in tree performance and in productivity due to climate change-induced drought stress (Hanson and Weltzin, 2000, Irvine et al. 2004, McDowell et al. 2008). This consideration is especially true for loblolly pine trees that are responsive to prolonged low soil water content (Oren et al. 1998, Ford et al. 2005, Domec et al. 2009), which decreases tree transpiration, gross primary productivity, and net carbon exchange (Noormets et al. 2010, Sun et al. 2010). Soil water content is the essential state variable in hydrologic studies of

Manuscript received April 28, 2011; accepted November 28, 2011; published online February 23, 2012; http://dx.doi.org/10.5849/forsci.11-051.

Jean-Christophe Domec, Bordeaux Sciences Agro, UMR 1220 TCEM ENITA/INRA, F-33175, Gradignan, North Carolina State University, Raleigh, NC 27606_Phone: (919) 687-7639; jdomec@ncsu.edu. Ge Sun, Eastern Forest Environmental Threat Assessment Center, USDA Forest Service, Raleigh, NC. Asko Noormets, Department of Forestry and Environmental Resources, North Carolina State University, Raleigh, NC. Michael J. Gavazzi, Eastern Forest Environmental Threat Assessment Center, USDA Forest Service, Raleigh, NC. Emrys A. Treasure, Eastern Forest Environmental Threat Assessment Center, USDA Forest Service, Raleigh, NC. Erika Cohen, Eastern Forest Environmental Threat Assessment Center, USDA Forest Service, Raleigh, NC. Jennifer J. Swenson, Nicholas School of the Environment, Duke University, Durham, NC. Steve G. McNulty, Eastern Forest Environmental Threat Assessment Center, USDA Forest Service, Raleigh, NC. John S. King, Department of Forestry and Environmental Resources, North Carolina State University, Raleigh, NC.

Acknowledgments: This study was supported by the USDA Forest Service Raleigh Eastern Forest Environmental Threat Assessment Center cooperative agreements 03-CA-11330147-073 and 04-CA-11330147-238, and the DOE-BER Terrestrial Ecosystem Sciences program, grant 11-DE-SC-0006700. We thank the Weyerhaeuser Company for facilitating access to the study site and offering logistical assistance. We thank Gena Simpson, Duncan Briley, Anna Barnes, and Crystal Garcia for conducting soil-pit digging and root sorting.

Copyright (C) 2012 by the Society of American Foresters. 
the land surface because it reflects short-term differences between inputs (e.g., precipitation) and outputs (e.g., ET, runoff, and drainage) of an ecosystem. Most ecohydrologic models are centered on soil water content (e.g., Sperry et al. 1998, Lai and Katul 2000, Barnard et al. 2010). Therefore, accurately defining the relationships between soil water content and water fluxes from the soil and the vegetation is fundamental to improving hydrologic modeling. However, to date the majority of field investigations have relied on monitoring the first $10-40 \mathrm{~cm}$ soil profile to characterize whole stand soil water depletion and water use, whereas the rooting zone is usually much deeper (Warren et al. 2005, Miller et al. 2007, Domec et al. 2010).

Variations in water balance across space and time are a function of interactions among species, environmental conditions, stand age, and silvicultural practices (Baldocchi et al. 2004, Moore et al. 2004). Evaluating the effects of even-aged forest management on ecosystem water budgets in the coastal regions of the United States has been the focal point of considerable research (McCarthy et al. 1991, Martin 2000, Sun et al. 2000, 2010, Powell et al. 2008) owing to concerns of possible impacts of expansions of plantations on water quality and quality. Widely used hydrologic and water quality models developed for these coastal regions (Amatya and Skaggs 2001) are rarely validated with actual ET, a major hydrologic flux. Furthermore, to evaluate the effects of periodic drought and better predict the impacts of climate change on ecosystem functions from plantations, it is critical to evaluate the response of each of the hydrologic components (Bond et al. 2008, Palmroth et al. 2010). Components of forest water loss may be determined by measuring the simultaneous differences between eddy covariance measurements $\left(\mathrm{ET}_{\mathrm{EC}}\right)$ and tree sapflow (e.g., Oren et al. 1998, Moore et al. 2004, Schwarzel et al. 2009). These two measures can then be compared with soil water content dynamics (Warren et al. 2005, Domec et al. 2010) and with soil evaporation (Raz-Yaseef et al. 2010a). Sap flow usually underestimates tree transpiration because of scaling errors, especially in mixed-species stands (Wilson et al. 2001, Williams et al. 2004, Ford et al. 2007). However, recently it has been shown that in tree plantations with a small number of plant species, $\mathrm{ET}_{\mathrm{EC}}$ compared well with sap flow measurements, once corrected for soil evaporation and understory transpiration (Domec et al. 2010, Oishi et al. 2010). This finding suggests that estimation of evaporation from soil and transpiration from the understory might be another source of error in such comparative tests.

Although ET is a key variable that links hydrologic and biologic processes and is critical to modeling watershed hydrology and carbon uptake (Amatya and Skaggs 2001, Sun et al. 2010), large uncertainties remain in its components because it is often too simply derived as the residual of the water balance. In this study, we present a multiyear comparison of three independent methods that estimate ET and its components. We first compared the $\mathrm{ET}_{\mathrm{EC}}$ method with the soil water content variation method $\left(\mathrm{ET}_{\mathrm{SM}}\right)$. These two techniques give comparable results on shallow soil, but $\mathrm{ET}_{\mathrm{EC}}$ is usually larger than $\mathrm{ET}_{\mathrm{SM}}$ on deep soils with the differences accentuated during drought (Wilson et al. 2001, Oishi et al. 2008). The observed discrepancies were often attributed to the uncertainty in scaling-up of soil moisture measurements within the entire soil profile (Schwarzel et al. 2009, Oishi et al. 2010), and so we also compared $\mathrm{ET}_{\mathrm{SM}}$ estimated from the upper soil profile with $\mathrm{ET}_{\mathrm{SM}}$ estimated from the whole soil profile. The third method, water table fluctuation $\left(\mathrm{ET}_{\mathrm{WT}}\right)$, is based on water level drawdown due to plant uptake and rebound due to underlying gradients in water head (White 1932). Although this technique can be applied on a large scale, it has not been widely used and validated using a comparison with other independent measurements of ET (Vincke and Thiry 2008, Loheide 2008). If proven to compare well, water level fluctuations could provide a useful tool for estimating stand water at low cost over large spatial scales. The objectives of this study were therefore threefold: to characterize the stand water balance in an early- and a mid-rotation loblolly pine plantation using three different approaches; to partition the water use between the loblolly pine trees, the understory trees and soil evaporation; and to evaluate the reliability/representativeness of soil moisture measurements by taking into account the observed variability in soil moisture dynamic by soil depth.

\section{Methods \\ Sites}

Both study sites are located within the lower coastal plain mixed forest province of North Carolina in the southeastern United States (Noormets et al. 2010, Sun et al. 2010). The loblolly pine plantations are owned and operated by Weyerhaeuser Company. The watersheds are drained with a network of parallel ditches (90-130 cm deep; 90-m spacing) and more widely spaced roadside canals. Drainage lowers the height of the water table, improving site access (management) and tree productivity by reducing stresses caused by excessive soil water conditions during winter months (Kelting et al. 2000). The long-term (1945-2010) average annual precipitation was $1,308 \pm 201 \mathrm{~mm}$, evenly distributed throughout the year. Long-term mean annual temperature averaged $15.5^{\circ} \mathrm{C}$, with a monthly high temperature occurring in July $\left(26.6^{\circ} \mathrm{C}\right)$ and a monthly low occurring in January $\left(6.4^{\circ} \mathrm{C}\right)$. The two study sites (US-NC1 and US-NC2 in the Ameriflux database) are $4 \mathrm{~km}$ apart, located at $35^{\circ} 11^{\prime} \mathrm{N}, 76^{\circ} 11^{\prime} \mathrm{W}$ and $35^{\circ} 48^{\prime} \mathrm{N}, 76^{\circ} 40^{\prime} \mathrm{W}$, respectively. The early-rotation plantation (US-NC1) is 48 ha in size, and the mid-rotation stand (US-NC2) is 100 ha. US-NC1 was clearcut in 2004 to remove an 80-year-old native hardwood forest and replanted in 2005 with 1-yearold loblolly pine seedlings (Table 1). The dense understory during the first years was primarily composed of Rubus ursinus (blackberry), Smilax rotundifolia (greenbrier), and Eupatorium capillofolium (dog fennel) and reached a height of 2-4 $\mathrm{m}$ in 2009. The soil is classified as Cape Fear Series fine, mixed, semiactive Typic Umbraquult. US-NC2 is a mid-rotation plantation that was established in 1992 after clearcutting the previous mature pine plantation. The histicmineral soil at this site is classified as Belhaven series. The understory was primarily composed of young red maple (Acer rubrum), devil's walking stick (Aralia spinosa), pokeweed (Phytolacca americana), beautyberry (Callicarpa 
Table 1. Stand characteristics in 2009 for the early-rotation and the mid-rotation loblolly pine plantations.

\begin{tabular}{|c|c|c|}
\hline & $\begin{array}{l}\text { Early-rotation } \\
\text { stand }\end{array}$ & $\begin{array}{l}\text { Mid-rotation } \\
\text { stand }\end{array}$ \\
\hline Stand age & 5 & 19 \\
\hline Canopy height (m) & 3.5 & 18.7 \\
\hline Tree spacing $(\mathrm{m})$ & 1.5 by 6 & 2.5 by 6 \\
\hline Density (tree $\mathrm{ha}^{-1}$ ) & 1,040 & 635 \\
\hline Tree dbh (m) & 0.14 & 0.35 \\
\hline Stand basal area $\left(\mathrm{m}^{2} \mathrm{ha}^{-1}\right)$ & 14.5 & 56.2 \\
\hline Tree LAI & $1.0-2.0$ & $3.0-4.2$ \\
\hline Total LAI & $1.2-4.1$ & $3.1-5.4$ \\
\hline Rooting depth (m) & 0.9 & 1.9 \\
\hline \multicolumn{3}{|l|}{ Soil characteristics ${ }^{a}$} \\
\hline $0-30 \mathrm{~cm}$ & $\begin{array}{l}\text { Organic matter/ } \\
\text { sandy loam }\end{array}$ & $\begin{array}{l}\text { Organic matter/ } \\
\text { sandy loam }\end{array}$ \\
\hline $30-60 \mathrm{~cm}$ & Sandy loam & $\begin{array}{l}\text { Organic matter/ } \\
\text { sandy loam }\end{array}$ \\
\hline $60-90 \mathrm{~cm}$ & Sandy clay & Sandy loam \\
\hline $90-180 \mathrm{~cm}$ & Sandy clay & Sandy clay \\
\hline \multicolumn{3}{|l|}{ Field capacity $\left(\mathrm{m}^{3} \mathrm{~m}^{-3}\right)$} \\
\hline $0-60 \mathrm{~cm}$ & 0.48 & 0.56 \\
\hline $60-180 \mathrm{~cm}$ & $0.40^{\mathrm{b}}$ & 0.37 \\
\hline \multicolumn{3}{|l|}{$\begin{array}{l}\text { Specific yield } \\
\quad(\text { dimensionless })^{b}\end{array}$} \\
\hline $0-60 \mathrm{~cm}$ & 0.145 & 0.16 \\
\hline $60-180 \mathrm{~cm}$ & 0.09 & 0.07 \\
\hline
\end{tabular}

Note that the age of the stand is from planting date and the actual tree ages at both sites were 1 year older (because it included the nursery period). Tree density refers to the number of live trees in 2009 and not to the original planting tree density. LAIs represent minimum and maximum values averaged for 2007 to 2009. Canopy height, tree diameter, stand basal area, and LAI were determined from the 13 vegetation survey plots surrounding the eddy flux tower and followed field protocols for forest vegetation sampling (Law et al. 2009).

${ }^{a}$ Data from Diggs (2004), Grace et al. (2006), and Domec et al. (2010).

${ }^{\mathrm{b}}$ Data from Diggs (2004).

americana), giant cane (Arundinaria macrosperma), and Meadow grass (Poa spp.) (Domec et al. 2010).

Forest projected leaf area index (LAI) at the mid-rotation site was measured using a LAI-2000 Plant Canopy Analyzer (LI-COR Inc., Lincoln, NE). More details on LAI measure- ments at this site are given in Domec et al. (2009) and Noormets et al. (2010). The optical method was not appropriate because of the open canopy at the early-rotation site, so minimum LAI (winter LAI) was measured destructively on 6-10 trees harvested in late winter every year. The seasonal change in tree LAI at this site was calculated using the seasonal pattern in current-year needle elongation and previous-year needle loss (Domec et al. 2009). The variation curve of total LAI (trees and understory vegetation combined) was determined based on the MODIS-LAI product (Knyazikhin et al. 1998, Oak Ridge National Laboratory Distributed Active Archive Center 2010), which is an 8-day interval time series, and had a total of 43 scenes per year at our sites. Retrieved data were corrected at the early-rotation site for land cover misclassification. MODIS-LAI data were also corrected by applying a canopy extinction coefficient of 0.5 specific to a loblolly pine plantation (Synclair and Knoerr 1982). During winter, when understory LAI was close to 0 (Table 2), MODIS-LAI was highly correlated with tree LAI at both sites (MODIS-LAI $=1.03$ trees LAI; $r^{2}=0.83, P<0.001$, data not shown). After field protocols for forest vegetation sampling (Law et al. 2009), at the mid-rotation site we also measured the seasonal change in leaf loss using 30 litter traps $\left(0.18 \mathrm{~m}^{2}\right.$ screen-lined laundry baskets) collected every 6 weeks during spring and summer and every 2 weeks during fall and early winter. Litter basket measurements indicated that broadleaf species and understory plants accounted for $16-18 \%$ of annual leaf dry biomass. Because specific leaf area of these broadleaf species is approximately 3.5 times higher than pine specific leaf area (Domec et al. 2010), we estimated that understory LAI represented approximately $58 \%$ of 1 -year pine leaf area (one cohort of needles). Over the 3-year period, one cohort of pine needles taken as winter tree LAI equaled 2.9, putting maximum understory LAI estimated from litter baskets at approximately 1.6. This number was within $10 \%$ of the difference (1.7) measured between MODIS-LAI and maximum tree LAI, indicating that these two techniques could be

Table 2. Monthly winter (averaged between November and February) ET from ET $\mathbf{T}_{\mathbf{E C}}$ and its partitioning between the evaporative components $\left(I\right.$ and $\left.E_{S}\right)$ and the transpirational components ( $T$ and understory transpiration) along with LAI of trees and understory plants.

\begin{tabular}{|c|c|c|c|}
\hline & $\begin{array}{l}\text { Winter } \\
2007\end{array}$ & $\begin{array}{l}\text { Winter } \\
2008\end{array}$ & $\begin{array}{l}\text { Winter } \\
2009\end{array}$ \\
\hline \multicolumn{4}{|l|}{ 4-yr early-rotation } \\
\hline $\mathrm{ET}_{\mathrm{EC}}\left(\mathrm{mm} \mathrm{mo}^{-1}\right)$ & $32 \pm 4$ & $33 \pm 3$ & $31 \pm 6$ \\
\hline$I\left(\mathrm{~mm} \mathrm{mo}^{-1}\right)$ & $2 \pm 1$ & $2 \pm 1$ & $3 \pm 2$ \\
\hline $\mathrm{E}_{\mathrm{S}}\left(\mathrm{mm} \mathrm{mo}^{-1}\right)$ & $9 \pm 3$ & $9 \pm 1$ & $12 \pm 2$ \\
\hline$T\left(\mathrm{~mm} \mathrm{mo}^{-1}\right)$ & $\mathrm{NA}$ & $14 \pm 1$ & $17 \pm 2$ \\
\hline Understory transpiration $\left(\mathrm{mm} \mathrm{mo}^{-1}\right)=\mathrm{ET}_{\mathrm{EC}^{-}}-\mathrm{E}_{\mathrm{S}}-I$ & NA & $6 \pm 3$ & $1 \pm 2$ \\
\hline Tree LAI & 1.0 & 1.2 & 1.4 \\
\hline Understory LAI & 0.1 & 0.3 & 0.2 \\
\hline \multicolumn{4}{|l|}{ 17-yr mid-rotation } \\
\hline $\mathrm{ET}_{\mathrm{EC}}\left(\mathrm{mm} \mathrm{mo}^{-1}\right)$ & $41 \pm 5$ & $44 \pm 6$ & $56 \pm 3$ \\
\hline$I\left(\mathrm{~mm} \mathrm{mo}^{-1}\right)$ & $8 \pm 1$ & $6 \pm 1$ & $9 \pm 2$ \\
\hline $\mathrm{E}_{\mathrm{S}}\left(\mathrm{mm} \mathrm{mo}^{-1}\right)$ & $6 \pm 2$ & $5 \pm 1$ & $6 \pm 1$ \\
\hline$T\left(\mathrm{~mm} \mathrm{mo}^{-1}\right)$ & $25 \pm 3$ & $33 \pm 2$ & $37 \pm 5$ \\
\hline Understory transpiration $\left(\mathrm{mm} \mathrm{mo}^{-1}\right)=\mathrm{ET}_{\mathrm{EC}^{-}}-T-\mathrm{E}_{\mathrm{S}}-I$ & $2 \pm 2$ & $<1 \pm 1$ & $3 \pm 3$ \\
\hline Tree LAI & 2.9 & 3.0 & 3.1 \\
\hline Understory LAI & 0.4 & 0.1 & 0.2 \\
\hline
\end{tabular}

Data are means $\pm \mathrm{SD}$. NA, not applicable. 
used to partition tree LAI between trees and understory plants throughout the year.

\section{Microclimatic Conditions, Soil Moisture, and Stand Water Balance}

At each site, the following micrometeorologic parameters were measured above the canopy: relative humidity and air temperature (HMP45AC; Vaisala, Helsinki, Finland), photosynthetic photon flux density (LI-190; LI-COR, Inc.), and gross precipitation (TE-525; Campbell Scientific, Logan, UT). Data were recorded at a 30-minute interval using multiple dataloggers (CR1000 and CR5000 dataloggers; Campbell Scientific).

A simplified closed water balance equation was developed as

$$
P=\mathrm{ET}+D+\Delta \mathrm{S}_{\theta}
$$

where $P$ denotes gross precipitation, ET is defined as the sum of soil evaporation $\left(\mathrm{E}_{\mathrm{S}}\right)$, tree transpiration $(T)$, understory transpiration, and canopy interception $(I), D$ is drainage flowing out of the watershed, and $\Delta \mathrm{S}_{\theta}$ represents the change in soil water storage (all in $\mathrm{mm}_{\text {year }}{ }^{-1}$ ). Drainage was estimated from previous published relationships relating drainage flow rate measured with a weir and water table elevation recorded by the wells (Diggs 2004, Grace et al. 2006).

Continuous water table fluctuations were recorded at 1-hour intervals with a WL40 pressure transducer (Global Water, Port Orange, FL) monitoring well at each site, located less than $15 \mathrm{~m}$ from the eddy flux towers (measurement depth $=220$ and $130 \mathrm{~cm}$ at the mid-rotation and early-rotation site, respectively). $\Delta \mathrm{S}_{\theta}$ is the amount of water that is being added to or removed from the unsaturated soil layers and was calculated using volumetric soil water content $(\theta)$ measured with soil moisture probes consisting of multiple annular capacitance sensors (Sentek Pty. Ltd., Adelaide, Australia), separated vertically by $10 \mathrm{~cm}$ or more (Brooks et al. 2002). Except for the very top sensors (5-15 $\mathrm{cm})$, these probes are relatively insensitive to fluctuations in soil temperature and thus remain highly applicable for establishing the magnitude in $\theta$ and suited for year-round observation of soil moisture conditions (Warren et al. 2005, 2011). Two probes were installed to a depth of $1.4 \mathrm{~m}$ with eight independent sensors per probe at the mid-rotation site. Similarly, two probes were installed to a depth of $0.8 \mathrm{~m}$ with six independent sensors per probe at the early-rotation site. At both sites these maximum sampled depths encompassed more than $90 \%$ of the rooting zone (Domec et al. 2010). Each sensor was calibrated from soil cores taken at each sensor depth. In addition to the Sentek probes, at each site $\theta$ was also measured over the top $30 \mathrm{~cm}$ of the soil profile using four vertically inserted CS616 time domain reflectometers (Campbell Scientific). Moreover, to address the uncertainty in the $\theta$ measurements, we also compared $\theta$ determined with the Sentek probes to four extra CS616 time domain reflectometers inserted horizontally at four different depths $(0-10,10-20,20-30$, and $30-40 \mathrm{~cm})$. Such comparisons showed no difference in the pattern in soil moisture between the two systems with a $3-4 \%$ difference in $\theta(P=$
0.39 , Student's paired $t$-test). To compare across sites and to erase the influence of soil texture on $\theta$, drought intensity was also quantified in the form of relative extractable soil water (dimensionless), as defined by Bréda et al. (2006).

Closure errors (percentage) for annual water balances were computed based on McCarthy et al. (1991):

$$
\% \text { Error }=\left(\Delta \mathrm{S}_{\theta_{-} m}-\Delta \mathrm{S}_{\theta}\right) / Q \times 100
$$

where $Q$ is the system flux (in mm) expressed as

$$
Q=\left(P+D+\mathrm{ET}+\left|\Delta S_{\theta}\right|\right) / 2
$$

$\Delta \mathrm{S}_{\theta \_\mathrm{m}}$ represents the modeled $\Delta \mathrm{S}_{\theta}$ estimated as the residual in Equation 1, and $\Delta \mathrm{S}_{\theta}$ was calculated from the measured change in $\theta$ from using either the whole soil profile or the upper soil layers (first $30 \mathrm{~cm}$ ). To scale up to the whole rooting zone when the upper soil layers only are used, $\Delta \mathrm{S}$ of the upper soil $\left(\Delta \mathrm{S}_{\theta_{-} \text {top } 30 \mathrm{~cm}}\right)$ was weighted by the root area $\left(A^{\text {root}}\right)$ profile as detailed in Baldocchi et al. (2004):

$$
\Delta \mathrm{S}_{\theta}=\Delta \mathrm{S}_{\theta_{-} \text {top } 30 \mathrm{~cm}} \times \frac{A_{\text {total }}^{\text {root }}}{A_{\text {top } 30 \mathrm{~cm}}^{\text {Rot }}}
$$

\section{Evapotranspiration Based on Unsaturated Soil Moisture Depletion and Water Table Fluctuation}

Total $\mathrm{ET}_{\mathrm{SM}}$ was calculated as the difference between the maximum and minimum soil water storage measured within a 24-hour period (Brooks et al. 2002, Warren et al. 2007). Intercepted precipitations were added to the calculations of soil water loss to compare $\mathrm{ET}_{\mathrm{SM}}$ with $\mathrm{ET}_{\mathrm{EC}}$ values:

$$
\mathrm{ET}_{\mathrm{SM}_{\mathrm{d}}}=\sum_{i=1}^{n}\left(\theta_{\mathrm{i}, \mathrm{d}-1}-\theta_{\mathrm{i}, \mathrm{d}}\right) z_{i}+I_{\mathrm{d}}
$$

where $\theta_{\mathrm{i}, \mathrm{d}}$ is the volumetric soil water content $\left(\mathrm{m}^{3} \mathrm{~m}^{-3}\right)$ of layer $i$ on day $d, z_{\mathrm{i}}$ is the thickness of soil layer $i, n$ is the number of soil layers ( 5 and 8 layers at the early- and mid-rotation sites, respectively), and $I$ is the canopy interception. Soil water depletion was not estimated on days after rain events. Soil moisture during such days, as well as between adjacent sensors was interpolated linearly. After $\Delta \mathrm{S}_{\theta}$, the estimation of $\mathrm{ET}_{\mathrm{SM}}$ based on the upper soil layer measurements was determined by weighting soil water depletion of the upper $30 \mathrm{~cm}$ by the root area profile.

In addition to the soil water balance method, we also used the water table fluctuation to estimate ET. The method is based on the assumption that a drop in the water table is due to ET and drainage, and a rise in the water table is due to groundwater recharge (White 1932). Recharge is calculated as the product of the change in water level over time and specific yield. This approach is a gross simplification of a complex phenomenon, involving the movement of water to and from the water table (Healy and Cook 2002, Hill and Neary 2007) but has recently been used successfully in forest ecosystems to estimate ET (Loheide 2008, Vincke and Thiry 2008). Recharge by the water table fluctuation method was estimated with the following equation for days with no precipitation (White 1932, Vincke and Thiry 2008):

$$
\mathrm{ET}_{\mathrm{WT}_{\mathrm{d}}}=(\Delta \mathrm{S} / t+24 R) \times Y_{s}+I_{\mathrm{d}}
$$


where $\Delta \mathrm{S} / t$ is the change in storage for a day of time $t$ found by linear change in water table depth and $R$ is the recovery rate (per hour): the rate of nighttime positive change in water table height (without transpiration). The specific yields (dimensionless) or soil drainable porosity, $Y_{\mathrm{s}}$, for our studied sites were taken from Diggs (2004). For the soil rooting zone, specific yields varied on average from 0.125 at the mid-rotation site to 0.14 at the early-rotation site (Table 1).

\section{Evapotranspiration Estimated Using the Eddy Covariance Method $\left(E T_{E C}\right)$}

The eddy covariance towers were located in the middle of the stands and canopy latent heat $(\lambda E)$ fluxes were measured using an open-path infrared gas analyzer (LI-7500; LI-COR, Inc.) and a three-dimensional sonic anemometer (CSAT3; Campbell Scientific). The data were processed as reported previously (Noormets et al. 2010, Sun et al. 2010). In brief, the 30-minute mean fluxes of $\mathrm{H}_{2} \mathrm{O}$ were calculated as the covariance of vertical wind speed and the concentration of $\mathrm{H}_{2} \mathrm{O}$, representing the total water loss, including soil evaporation and canopy interception. Data were corrected for the warming of the infrared gas analyzer and for fluctuations in air density (Burba et al. 2008), and data quality was judged by atmospheric stability and flux stationarity during periods of well-developed turbulence as reported previously (Noormets et al. 2008). We also screened spurious or incomplete half-hourly data resulting from system malfunction or environmental disturbance. Gaps in 30-minute ET data, which amounted to 7, 14, and $8 \%$ for 2007, 2008, and 2009 at the mid-rotation site and to 4,24 , and $12 \%$ at the early-rotation site for 2007, 2008, and 2009, respectively, were filled using empirical monthly correlations between observed ET and Food and Agriculture Organization potential evapotranspiration (PET) (Noormets et al. 2010, Sun et al. 2010). Daily ET $_{\mathrm{EC}}$ was estimated by summing half-hourly above canopy eddy covariance ecosystem $\lambda \mathrm{E}$ values.

\section{Components of ET: Canopy Interception, Soil Evaporation, Pine Transpiration, and Understory Transpiration}

Interception represents evaporation losses during and after rain from the wet leaf surfaces that intercept rainfall. At the mid-rotation site, $I$ was determined from the difference between rainfall measured above the canopy and throughfall measured under the canopy using 10 manual rain gauges with a site visit every $2-3$ weeks. Trunk stemflow was not explicitly considered because it represented less than $1 \%$ of precipitation at these sites (Sun et al. 2010). For a given species, $I$ varies with forest age, species, and management factors such as spacing and thinning. For conifers it is primarily a function of tree size and thus LAI (Barbier et al. 2009). For the early-rotation site, $I$ was estimated using a relationship between stand basal area and total precipitation determined on similar loblolly pine stands (Stogsdill et al. 1989).

Soil evaporation $\left(E_{S}\right)$ was measured using an $8100 \mathrm{Au}-$ tomated Soil $\mathrm{CO}_{2}$ Flux System (LI-COR, Inc.) with 8100-101 and 8100-104 automatic chambers. The instrument was initially designed for soil $\mathrm{CO}_{2}$ efflux measurements but includes a high-precision $\mathrm{H}_{2} \mathrm{O}$ detector. Furthermore, it has been shown that $\mathrm{H}_{2} \mathrm{O}$ concentration increases linearly in the first 45-80 seconds, allowing reliable estimation of $E_{S}$ (Raz-Yaseef et al. 2010a, 2010b). Chamberbased soil vapor flux was measured in two soil collars permanently placed at both sites. Measurements were done every 3-5 weeks throughout the entire research period and maximum daily $E_{S}$ was calculated at half-hour time intervals between 1,000 and 1,400 hours corresponding with the time of peak in diurnal ET. Multilinear correlations between $\mathrm{E}_{\mathrm{S}}$ and $\theta$ and between $\mathrm{E}_{\mathrm{S}}$ and vapor pressure deficit were used to estimate $E_{S}$ for other periods (Raz-Yaseef et al. 2010a).

Unlike the eddy covariance technique that measures total ET, the sap flow method only measures $T$ and does not account for $I, \mathrm{E}_{\mathrm{S}}$, and the water transpired by understory plants. We measured sap flux density per unit of conducting xylem area $\left(J_{\mathrm{s}}, \mathrm{g} \mathrm{m}^{-2} \mathrm{~s}^{-1}\right)$ in stem xylem of seven trees at both sites. Stem sap flux measurements were made at $0.60 \mathrm{~m}$ above the ground at the early-rotation site and at $1.4 \mathrm{~m}$ above the ground at four radial positions at the mid-rotation site using $20-\mathrm{mm}$ heat dissipation probes (Granier 1987). Preliminary results showed that there was no significant difference in azimuthal $J_{\mathrm{s}}$ within trees $(P=$ $0.27, F$-test), probably owing to the homogeneity of pine trunks. Therefore, we inserted all probes on the north-northwest side of the trees (Domec et al. 2009). Thirty-minute averages of temperature difference data were computed and stored in data loggers (CR10; Campbell Scientific). The sensor signal was converted to $J_{\mathrm{s}}$, according to Granier (1987), and accounted for the effects of nonzero nighttime fluxes on the signal baseline (Oishi et al. 2008). Using tree sapwood area and stand tree density (Table 1), $J_{\text {s }}$ was scaled and converted to a tree-scale average $T$ per unit ground area $\left(\mathrm{mm} \mathrm{d}^{-1}\right)$. The total sapwood area of the trees equipped with sapflow probes was estimated from the relationship between sapwood area and diameter determined on 22 felled trees and on the diameter of the measured standing trees. Further details on the sap flow method were reported earlier (Domec et al. 2009, 2010). To estimate missing sap flux data, we developed time series models predicting daily $T$ from climate variables (vapor pressure deficit and photosynthetically active radiation) according to Ford et al. (2005). Missing data resulting from thunderstorms or from probe destruction by bears occurred less than $8 \%$ of the time. Because $80 \%$ of the missing data occurred on rainy days, the potential flux and the potential impact of the error associated with this prediction were assumed to be low.

\section{Statistical Analysis}

Unless otherwise noted in the text the SAS procedure Proc Mixed, which considers the influence of time on the variances of a variable examined (day of year as the repeated measure), was used to test the differences of the means of key observed micrometeorologic and hydrologic 
variables between both sites. The significance of leastsquares differences among years was calculated with a multiple range test using the Tukey-Kramer test for unbalanced samples.

\section{Results}

\section{Seasonal Soil Water Dynamics}

The 2007 and 2008 growing seasons experienced an extreme drought, with annual precipitation being 37-41\% (350-400 $\mathrm{mm}$ ) below the 65-year mean (Figure 1). At the beginning of the study in April-May of 2007, the soil was close to field capacity at both sites with the water table level at $30-\mathrm{cm}$ depth and $\theta$ of the entire rooting zone ranging from 0.35 to $0.41 \mathrm{~m}^{3} \mathrm{~m}^{-3}$ (Figure 2A). The water table fell during the subsequent dry period, and summer and fall water tables in 2007 and 2008 were generally much lower than in 2009 (Figure 2A). In June and again between August and November, gradual soil drying occurred. In the mid-rotation stand, the water table level dropped below $1.9 \mathrm{~m}$, and $\theta$ fell to $0.11 \mathrm{~m}^{3} \mathrm{~m}^{-3}$ for the $0-60 \mathrm{~cm}$ layer and to $0.19 \mathrm{~m}^{3}$ $\mathrm{m}^{-3}$ for the $60-120 \mathrm{~cm}$ layer. At this site, field capacity and $100 \%$ relative extractable soil water were almost reached again in 2008 for the deeper soil layers when rain events caused a transient partial recovery of $\theta$ (data not shown). A series of winter storm events in October and November 2009 (including Hurricane Ida), with a total of $189 \mathrm{~mm}$ of precipitation in 4 days, caused water levels at both stands to rise to near the soil surface. Both the groundwater table level and $\theta$ indicated that the early-rotation site was wetter than the mid-rotation site with relative extractable water never declining below 20\% (Figure 2B). Even in 2007 and 2008 , the soil profile at the early-rotation site was periodically saturated during winter and fall or after significant rain events (storms) in the summer. At the mid-rotation site, soil field capacity was not reached again from March 2008 to November 2009, and the relative extractable soil water remained less than $40 \%$ during most of this period (Figure 2B).

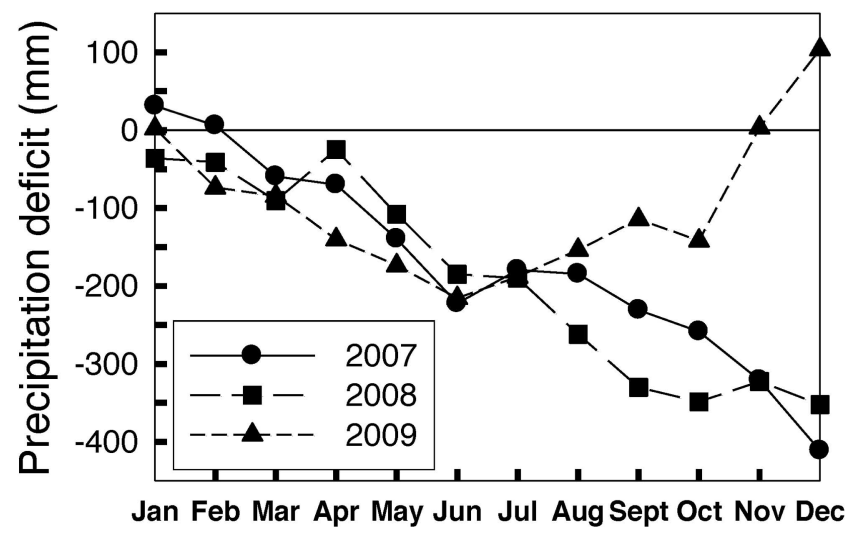

Figure 1. Annual course of monthly mean precipitation deficit compared with the 65-year mean (1945-2010, horizontal line) during the 3 year-study period at a loblolly pine plantation in the lower coastal plain in North Carolina, USA.

\section{Components of Stand Evapotranspiration and Water Balance}

Over the 3-year period, ecosystem-level evapotranspiration, as estimated with $\mathrm{ET}_{\mathrm{EC}}$, was $20-30 \%$ higher $(P=$ $0.02)$ at the mid-rotation site $\left(943 \pm 35 \mathrm{~mm}\right.$ year $\left.^{-1}\right)$ than at the early-rotation site $\left(742 \pm 74 \mathrm{~mm} \mathrm{year}^{-1}\right)$. However, significant differences in $\mathrm{ET}_{\mathrm{EC}}$ occurred between the first 2 dry years and the last wet year. The severe droughts of 2007 and 2008 resulted in a $16-20 \%$ and $<5 \%$ reduction in $\mathrm{ET}_{\mathrm{EC}}$ compared with 2009 at the early- and mid-rotation sites, respectively. Between sites, $\mathrm{ET}_{\mathrm{EC}}$ at the early-rotation site during the 2007 and 2008 droughts was 23\% lower $(P=$ $0.016)$ than at the mid-rotation site and only $11 \%$ lower $(P=0.055)$ in 2009 , when soil water was more available (Table 3). The smaller difference in $\mathrm{ET}_{\mathrm{EC}}$ between stands in 2009 could in part be attributed to increasing LAI at the early-rotation site (Table 1). At both sites the evaporative demand as characterized by PET did not significantly change between years $(P>0.34)$ (Table 3$)$. However, PET was $15 \%$ lower at the early-rotation site in $2007(P=0.02)$ but not in 2008 and $2009(P>0.31)$. The $\mathrm{ET}_{\mathrm{EC}}$ change was related to precipitation change at the early-rotation site $\left(\mathrm{ET}_{\mathrm{EC}}=0.77 \times P, r^{2}=0.81, P=0.02\right)$ but not at the mid-rotation site where the dry years did not significantly reduced $\operatorname{ET}_{\mathrm{EC}}(P=0.47)$. During the dry years, $\mathrm{ET}_{\mathrm{EC}}$ at the mid-rotation site was 3-12\% higher than $P$ and $20 \%$ lower during the wet year (or $246 \mathrm{~mm} \mathrm{year}^{-1}$ less). As a consequence, over the 3 year-period, the water loss through $D$ at the mid-rotation site represented less than $15 \%$ of $P$, compared with more than $23 \%$ at the early-rotation site (Table 3 ). Canopy interception was a small but significant contribution to ET, reaching $10 \%$ of annual $P$ on average.

Stand-scale soil evaporation $\left(\mathrm{E}_{\mathrm{S}}\right)$ measurements were estimated to be on average $103 \pm 9$ and $83 \pm 6 \mathrm{~mm}_{\text {year }}{ }^{-1}$ at the early- and mid-rotation sites, respectively (Table 3). Between 2007 and 2009, there was little variation in $E_{S}$ despite variation in rainfall over this period. Soil evaporation represented up to 13 and $25 \%$ of ET in May/June at the mid-rotation and early-rotation site, respectively, but only $7 \%$ in September/October at both sites. In the early-rotation stand, annual $\mathrm{E}_{\mathrm{S}}$ decreased from 16 to $11 \%$ from 2007 to $2009(P=0.04)$.

\section{Evapotranspiration Method Comparison}

At the mid-rotation site, ET estimates from soil water depletion $\left(\mathrm{ET}_{\mathrm{SM}}\right)$ were calculated using all soil moisture sensors and therefore represented water used for the first $1.4 \mathrm{~m}$ in depth where more than $90 \%$ of the roots were located (Table 1). The amount of water used in this $1.4 \mathrm{~m}$ of soil reached a maximum of $6.1 \mathrm{~mm} \mathrm{~d}^{-1}$, with an average of $4.2 \mathrm{~mm} \mathrm{~d}^{-1}$ through the summer (Figure 3A-C). At the mid-rotation stand, rates of $\mathrm{ET}_{\mathrm{SM}}$ were consistent on a daily basis with rates of $\mathrm{ET}_{\mathrm{EC}}$ (Figure $3 \mathrm{~B}$ and $\mathrm{C}$ ). However, the daily variations of $\mathrm{ET}_{\mathrm{SM}}$ as a function of $\mathrm{ET}_{\mathrm{EC}}$ showed a clockwise hysteresis, reflecting a lagging effect between soil water depletion and stand water loss (Figure 4). At the mid-rotation site, although monthly $\mathrm{ET}_{\mathrm{SM}}$ across the 3 years was highly correlated with $\mathrm{ET}_{\mathrm{EC}}$ (Figure 5), $\mathrm{ET}_{\mathrm{EC}}$ was $12 \%$ 


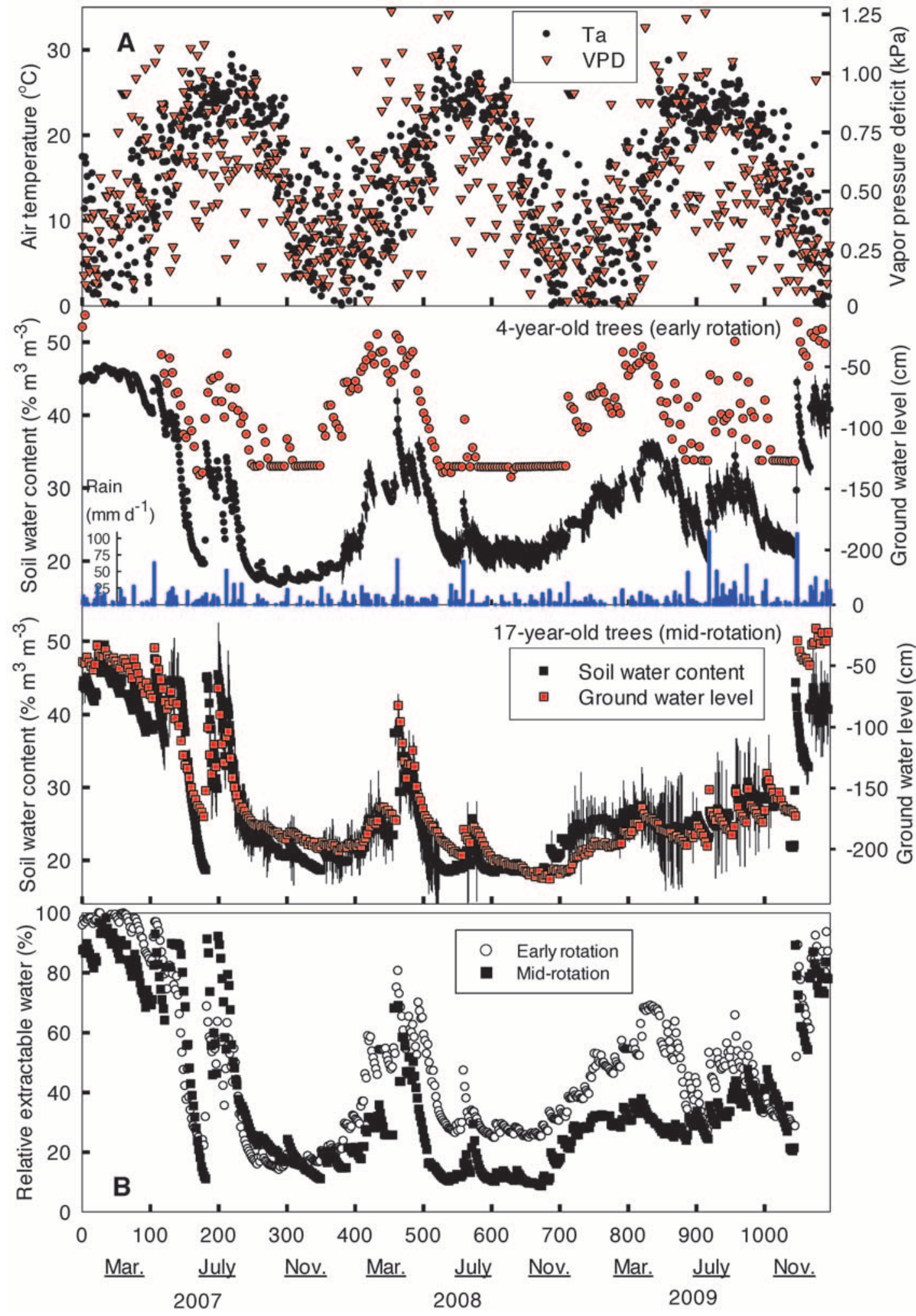

Figure 2. The annual course of daily mean air temperature (Ta), vapor pressure deficit (VPD), and the comparison of daily soil moisture dynamic, water table fluctuation (A), and relative extractable water (B) averaged over the entire soil profile between an early-rotation $(\odot)$ and a mid-rotation pine $(\square)$ site from 2007 to 2009, both located within the outer coastal plain of North Carolina.

lower than $\mathrm{ET}_{\mathrm{SM}}$ in the wet year (2009). Moreover, the correlation between $\mathrm{ET}_{\mathrm{EC}}$ and $\mathrm{ET}_{\mathrm{SM}}$ was highest for the driest year $\left(r^{2}=0.79, P=0.02\right)$ and lowest for the wettest year $\left(r^{2}=0.53, P=0.03\right)$. At the early-rotation site, monthly $\mathrm{ET}_{\mathrm{SM}}$ across the 3 years was also correlated with
$\mathrm{ET}_{\mathrm{EC}}$ (Figure 5), and the slope between $\mathrm{ET}_{\mathrm{SM}}$ and $\mathrm{ET}_{\mathrm{EC}}$ was not significantly different from $1(P=0.39)$.

$\mathrm{ET}_{\mathrm{WT}}$ resulted in 3-year mean ET estimates of $839 \pm$ $106 \mathrm{~mm}$ year $^{-1}$ at the early-rotation site and 1,116 \pm 19 mm year ${ }^{-1}$ at the mid-rotation site (Table 3 ). At both sites, 
Table 3. Sum of ET measured from 2007 to 2009 with three different methods: $\mathbf{E T}_{\mathrm{EC}}, \mathrm{ET}_{\mathrm{WT}}$, and $\mathbf{E T}_{\mathrm{SM}}$.

\begin{tabular}{|c|c|c|c|}
\hline & 2007 & 2008 & 2009 \\
\hline \multicolumn{4}{|l|}{ 4-yr early-rotation } \\
\hline Precipitation $\left(\mathrm{mm} \mathrm{yr}^{-1}=\mathrm{kg} \mathrm{m}^{-2}\right.$ soil $\left.\mathrm{yr}^{-1}\right)$ & 907 & 882 & 1,240 \\
\hline Throughfall $\left(\mathrm{mm} \mathrm{yr}^{-1}\right)$ & 848 & 795 & 1,153 \\
\hline 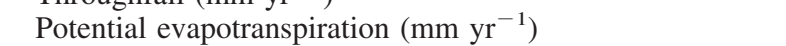 & 1,024 & 1,013 & 1,089 \\
\hline Evapotranspiration $\left(\mathrm{mm} \mathrm{yr}^{-1}\right)$ & 736 & 637 & 886 \\
\hline Interception $\left(\mathrm{mm} \mathrm{yr}^{-1}\right)$ & 35 & 57 & 101 \\
\hline Soil evaporation $\left(\mathrm{mm} \mathrm{yr}^{-1}\right)$ & $109 \pm 14$ & $111 \pm 31$ & $95 \pm 19$ \\
\hline Tree transpiration $\left(\mathrm{mm} \mathrm{yr}^{-1}\right)$ & NA & $192 \pm 26$ & $328 \pm 49$ \\
\hline Understory transpiration $\left(\mathrm{mm} \mathrm{yr}^{-1}\right)=\mathrm{ET}_{\mathrm{EC}}-T-\mathrm{E}_{\mathrm{S}}-I$ & NA & $277 \pm 43$ & $363 \pm 33$ \\
\hline Drainage $\left(\mathrm{mm} \mathrm{yr}^{-1}\right)$ & 248 & 233 & 213 \\
\hline Ground water table fluctuation $\left(\mathrm{mm} \mathrm{yr}^{-1}\right)$ & 757 & 667 & 1,095 \\
\hline Understory transpiration $\left(\mathrm{mm} \mathrm{yr}^{-1}\right)=\mathrm{ET}_{\mathrm{WT}^{-}}-T-\mathrm{E}_{\mathrm{S}^{-}} I$ & NA & $309 \pm 21$ & $569 \pm 31$ \\
\hline Soil water depletion $\left(\mathrm{mm} \mathrm{yr}^{-1}\right)$ & $659 \pm 51$ & $534 \pm 57$ & $881 \pm 91$ \\
\hline Understory transpiration $\left(\mathrm{mm} \mathrm{yr}^{-1}\right)=\mathrm{ET}_{\mathrm{SM}^{-}}-T-\mathrm{E}_{\mathrm{S}}-I$ & $\mathrm{NA}$ & $175 \pm 39$ & $357 \pm 41$ \\
\hline Modeled soil water storage $\left(\Delta \mathrm{S}_{\theta \mathrm{m}}, \mathrm{mm} \mathrm{yr}^{-1}\right)^{\mathrm{a}}$ & -79 & 8 & 138 \\
\hline$\%$ Error in soil water storage from whole soil profile ${ }^{a}$ & -8 & -5 & 7 \\
\hline$\%$ Error in soil water storage from upper soil profile ${ }^{a}$ & -9 & -4 & -11 \\
\hline \multicolumn{4}{|l|}{17 -yr mid-rotation } \\
\hline Precipitation $\left(\mathrm{mm} \mathrm{yr}^{-1}=\mathrm{kg} \mathrm{m}^{-2}\right.$ soil $\left.\mathrm{yr}^{-1}\right)$ & 892 & 925 & 1,282 \\
\hline Throughfall $\left(\mathrm{mm} \mathrm{yr}^{-1}\right)$ & 826 & 851 & 1,182 \\
\hline Potential evapotranspiration $\left(\mathrm{mm} \mathrm{yr}^{-1}\right)$ & 1,173 & 1,101 & 1,067 \\
\hline Evapotranspiration $\left(\mathrm{mm} \mathrm{yr}^{-1}\right)$ & 1,011 & 927 & 1,001 \\
\hline Interception $\left(\mathrm{mm} \mathrm{yr}^{-1}\right)$ & 66 & 74 & 57 \\
\hline Soil evaporation $\left(\mathrm{mm}^{-1} \mathrm{r}^{-1}\right)$ & $89 \pm 21$ & $79 \pm 19$ & $82 \pm 11$ \\
\hline Tree transpiration $\left(\mathrm{mm} \mathrm{yr}^{-1}\right)$ & $644 \pm 71$ & $648 \pm 82$ & $777 \pm 79$ \\
\hline 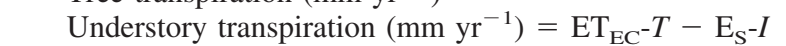 & $213 \pm 34$ & $116 \pm 20$ & $77 \pm 19$ \\
\hline Drainage $\left(\mathrm{mm} \mathrm{yr}^{-1}\right)$ & 255 & 61 & 196 \\
\hline Ground water table fluctuation $\left(\mathrm{mm} \mathrm{yr}^{-1}\right)$ & 1,117 & 1,134 & 1,097 \\
\hline Understory transpiration $\left(\mathrm{mm} \mathrm{yr}^{-1}\right)=\mathrm{ET}_{\mathrm{WT}}-T-\mathrm{E}_{\mathrm{S}}-I$ & $318 \pm 40$ & $333 \pm 69$ & $181 \pm 30$ \\
\hline Soil water depletion $\left(\mathrm{mm} \mathrm{yr}^{-1}\right)$ & $980 \pm 141$ & $1,004 \pm 128$ & $1,118 \pm 101$ \\
\hline Understory transpiration $\left(\mathrm{mm} \mathrm{yr}^{-1}\right)=\mathrm{ET}_{\mathrm{SM}^{-}}-T-\mathrm{E}_{\mathrm{S}^{-}}-I$ & $181 \pm 27$ & $203 \pm 46$ & $179 \pm 41$ \\
\hline Modeled soil water storage $\left(\Delta \mathrm{S}_{\theta \mathrm{m}}, \mathrm{mm} \mathrm{yr}^{-1}\right)^{\mathrm{a}}$ & -371 & -63 & $\overline{78}$ \\
\hline$\%$ Error in soil water storage from whole soil profile ${ }^{a}$ & -5 & 8 & 4 \\
\hline$\%$ Error in soil water storage from upper soil profile ${ }^{a}$ & -20 & 7 & 27 \\
\hline
\end{tabular}

$\mathrm{ET}_{\mathrm{EC}}$ was decomposed into $I, \mathrm{E}_{\mathrm{S}}, T$, and understory transpiration. Values of understory transpiration estimated using $\mathrm{ET}_{\mathrm{WT}}$ and $\mathrm{ET}_{\mathrm{SM}}$ are also given. $\mathrm{NA}_{\text {, }}$ not applicable.

${ }^{\mathrm{a}} \Delta \mathrm{S}_{\theta_{-} \mathrm{m}}$ represents the modeled $\Delta \mathrm{S}_{\theta}$ estimated as the residual in Equation 1. The closure errors (percentage) for annual water balance are given when soil water storage $\left(\Delta \mathrm{S}_{\theta}\right)$ was either calculated from the upper soil profile or from the whole soil profile (Equation 2).

$\mathrm{ET}_{\mathrm{WT}}$ was in good agreement with $\mathrm{ET}_{\mathrm{EC}}$ on a monthly basis (Figure 5) but not on a daily basis (Figures $3 \mathrm{~A}$ and $\mathrm{C}$ and 4). On a monthly basis, $\mathrm{ET}_{\mathrm{WT}}$ predicted $\mathrm{ET}_{\mathrm{EC}}$ better at the mid-rotation than at the early-rotation site with a slope varying around 0.85 (Figure 5). At the mid-rotation site, $\mathrm{ET}_{\mathrm{WT}}$ overestimated $\mathrm{ET}_{\mathrm{EC}}$ by $12-13 \%$ (Table 3 ; Figure 5) and $\mathrm{ET}_{\mathrm{SM}}$ by $10-12 \%$ (Table 3; correlation between $\mathrm{ET}_{\mathrm{WT}}$ and $\mathrm{ET}_{\mathrm{SM}}$ not shown).

\section{Comparison of ET and Soil Water Storage Using Whole-Profile and Upper Soil Water Content Variation}

At the early-rotation site, the upper soil layer predicted well the whole soil water content dynamic across the 3 -year period (Figure 6A). However, at the mid-rotation site, a counterclockwise hysteresis was apparent between $\theta$ measured throughout the whole soil profile and the upper soil profile. $\mathrm{ET}_{\mathrm{SM}}$ estimated from the upper $30 \mathrm{~cm}$ of soil weighted by the root distribution profile underestimated $\mathrm{ET}_{\mathrm{EC}}$ by more than $30 \%$ (Figure 6B). Similarly, upper soil $\theta$ fluctuations provided a poor estimate of $T$ (Figure 6B). Although the overall slopes between monthly $T$ and $\mathrm{ET}_{\mathrm{SM}}$ estimated from either the upper $30 \mathrm{~cm}$ of soil (Figure 6B) or from the whole soil profile (data not shown) were similar at both sites $(P=0.31)$, the overall fit decreased by more than $75 \%$.

Significant negative values of measured $\Delta \mathrm{S}_{\theta}$ were recorded in 2007 and 2008 as a consequence of sustained ET and low $P$ (Figure 7). At the early-rotation site, remaining soil water storage left was only $75 \mathrm{~mm}$ by the end of 2008 (Figure 7), which represented fewer than 3 months of $T$. Annual water budgets indicated that the modeled $\Delta \mathrm{S}_{\theta \_\mathrm{m}}$ (estimated as residual from Equation 1) varied from -371 to $78 \mathrm{~mm}$ at the mid-rotation stand and from -79 to 138 $\mathrm{mm}$ at the early-rotation stand. It can be noted that at the mid-rotation site, 2 consecutive years such as 2007 would have nearly depleted the estimated $780 \mathrm{~mm}$ of available water from the entire soil profile where roots are present. At the early-rotation site, monitoring the first $30 \mathrm{~cm}$ of soil moisture represented $\Delta \mathrm{S}_{\theta}$ accurately, as seen by the low closure errors (Table 3). At the mid-rotation site, $\Delta \mathrm{S}_{\theta}$ calculated using the first $30 \mathrm{~cm}$ of the soil profile induced closure errors for the water balances larger than $20 \%$ in both the driest and the wettest year (Table 3). 

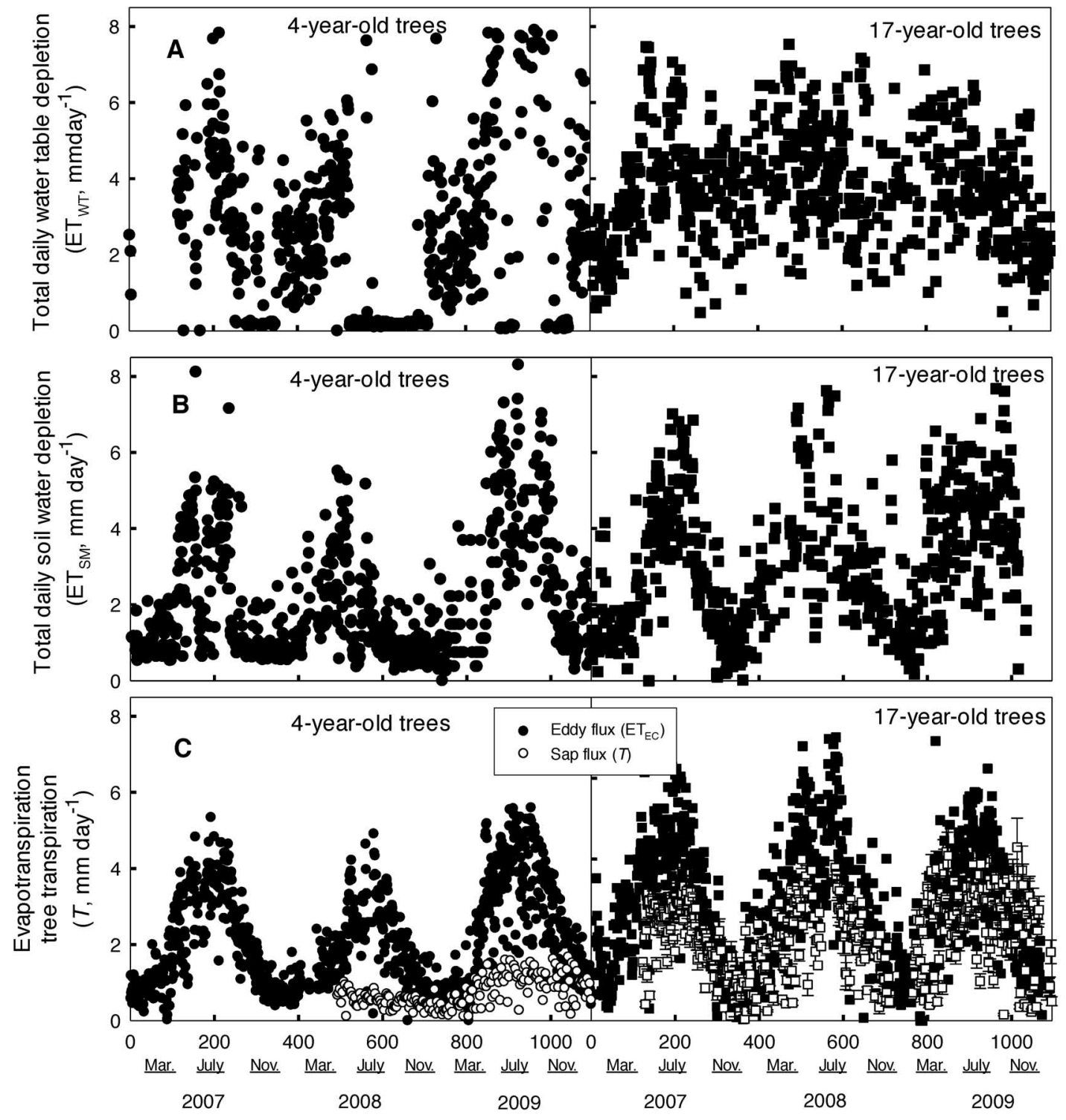

Figure 3. Daily average soil water depletion calculated using the water table fluctuation method (A), the soil water depletion of the entire soil profile $(B)$, and the total stand evaporation measured by the eddy covariance $\left(\mathrm{ET}_{\mathrm{EC}}\right)$ method $(\mathrm{C})$ between an early-rotation pine site and a mid-rotation site from 2007 to 2009, both located within the outer coastal plain of North Carolina. In C, pine transpiration is also given (T) with error bars $(n=7$ trees).

\section{Partitioning the Effect of Soil Evaporation, Tree Transpiration, and Understory Vegetation on the Water Balance}

Despite quantitative differences, the daily $T$ values estimated from sap flow and from $\mathrm{ET}_{\mathrm{EC}}$ were often qualitatively similar over the years (Figure 3C). During winter, the understory deciduous species at both stands were leafless and the overstory pine trees comprised almost $100 \%$ of total stand leaf area (Table 2), and the differences between $T$ and $\mathrm{ET}_{\mathrm{EC}}$ were explained by $I$ and $\mathrm{E}_{\mathrm{S}}$ (Table 2), indicating that understory transpiration was negligible $\left(<5 \mathrm{~mm} \mathrm{month}^{-1}\right)$. However, during the growing season, understory transpiration accounted for a large component of total $\mathrm{ET}_{\mathrm{EC}}$, averaging 50 and $14 \%$ of whole stand water use at the early- and mid-rotation site, respectively. At the mid-rotation site, the understory component declined from $22 \%$ in 2007 to $13 \%$ in 2008 to $9 \%$ in 2009. This sharp decline could be attrib- uted to a decrease in growing season understory LAI from 1.6 in 2007 to 1.4 in 2008 and to 1.2 in 2009 . Across years the correlation between understory LAI and understory transpiration was: transpiration understory $\left(\mathrm{mm}\right.$ month $\left.^{-1}\right)=$ $17.6 \times \mathrm{LAI}_{\text {understory }}+11.6\left(r^{2}=0.77, P<0.001\right)$ at the early-rotation site; transpiration understory $\left(\mathrm{mm} \mathrm{month}^{-1}\right)=$ $10.4 \times \mathrm{LAI}_{\text {understory }}\left(r^{2}=0.49, P<0.01\right)$ at the mid-rotation site. The early-rotation site with higher understory LAI relative to tree LAI (Table 1) had lower ET and higher drainage than the mid-rotation site (Table 3).

The use of $\mathrm{ET}_{\mathrm{WT}}$ to determine the understory component overestimated understory transpiration by more than 16 and $50 \%$ at the early- and mid-rotation sites, respectively (Table 3). Understory transpiration calculated using $\mathrm{ET}_{\mathrm{SM}}$ was underestimated at the early-rotation site by more than $20 \%$. At the mid-rotation site understory transpiration was overestimated by more than $40 \%$ in 2008 and 2009 (Table 3). 


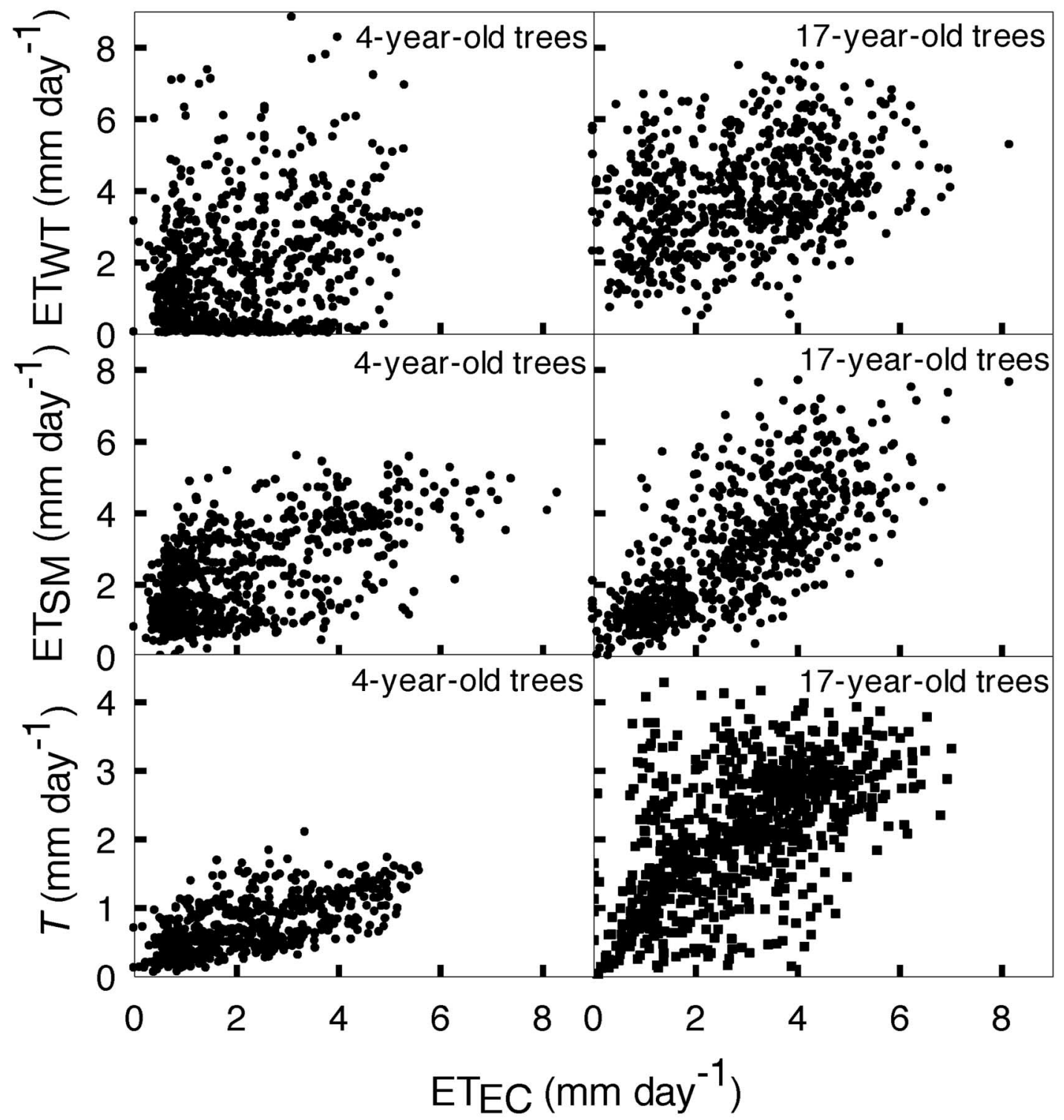

Figure 4. Daily sum of water uptake in the water table $\left(\mathbf{E} \mathbf{T}_{\mathbf{W T}}\right)$, soil water depletion of the entire soil profile $\left(\mathbf{E T}_{\mathrm{SM}}\right)$, and pine transpiration $(T)$ as a function of stand evapotranspiration measured with the eddy covariance method $\left(\mathrm{ET}_{\mathrm{EC}}\right)$.

\section{Discussion}

\section{Evapotranspiration: Comparison of Methods}

Consistent with an earlier analysis by Sun et al. (2010) for the same sites and by Gholz and Clark (2002) for a similar landscape, ET values were lower at the early-rotation site than at the mid-rotation site regardless of the method used. The differences were amplified when soil water was less available, suggesting that climatic variability could mask the ET differences among stands at different succession stages. In 2007, the difference in ET between sites was also partly explained by the difference in evaporative demand because PET was higher at the mid-rotation site because of higher surface temperature (Sun et al. 2010). However, during the last 2 years, the lower ET values measured at the early-rotation site were not the consequence of differences in PET. Between 2007 and 2009, the evaporative demand at the early-rotation site increased slightly, mirroring the increase in tree LAI and thus affecting surface albedo (Gibbard et al. 2005, Sun et al. 2010).

Soil moisture sensors have drawbacks for calculating ET, because they must be calibrated using soil cores and they integrate only a small soil volume. We acknowledge that the small number of soil moisture probes added some uncertainty in the absolute magnitude of the soil water fluxes. However, monthly $\mathrm{ET}_{\mathrm{SM}}$ values were highly correlated with $\mathrm{ET}_{\mathrm{EC}}$ (Figure 5), suggesting that the low number of probes did not affect negatively $\mathrm{ET}_{\mathrm{SM}}$ in extrapolating results to the same area of the eddy covariance tower. Moreover, comparisons with the time domain reflectometry probes also suggested that we accurately represented soil moisture. Finally, just as with the towers themselves, which are not replicated, the limited spatial representation of soil moisture is offset by the continuous nature of the monitoring. This allowed us to observe changes in system performance through time and in connection to environmental drivers. 


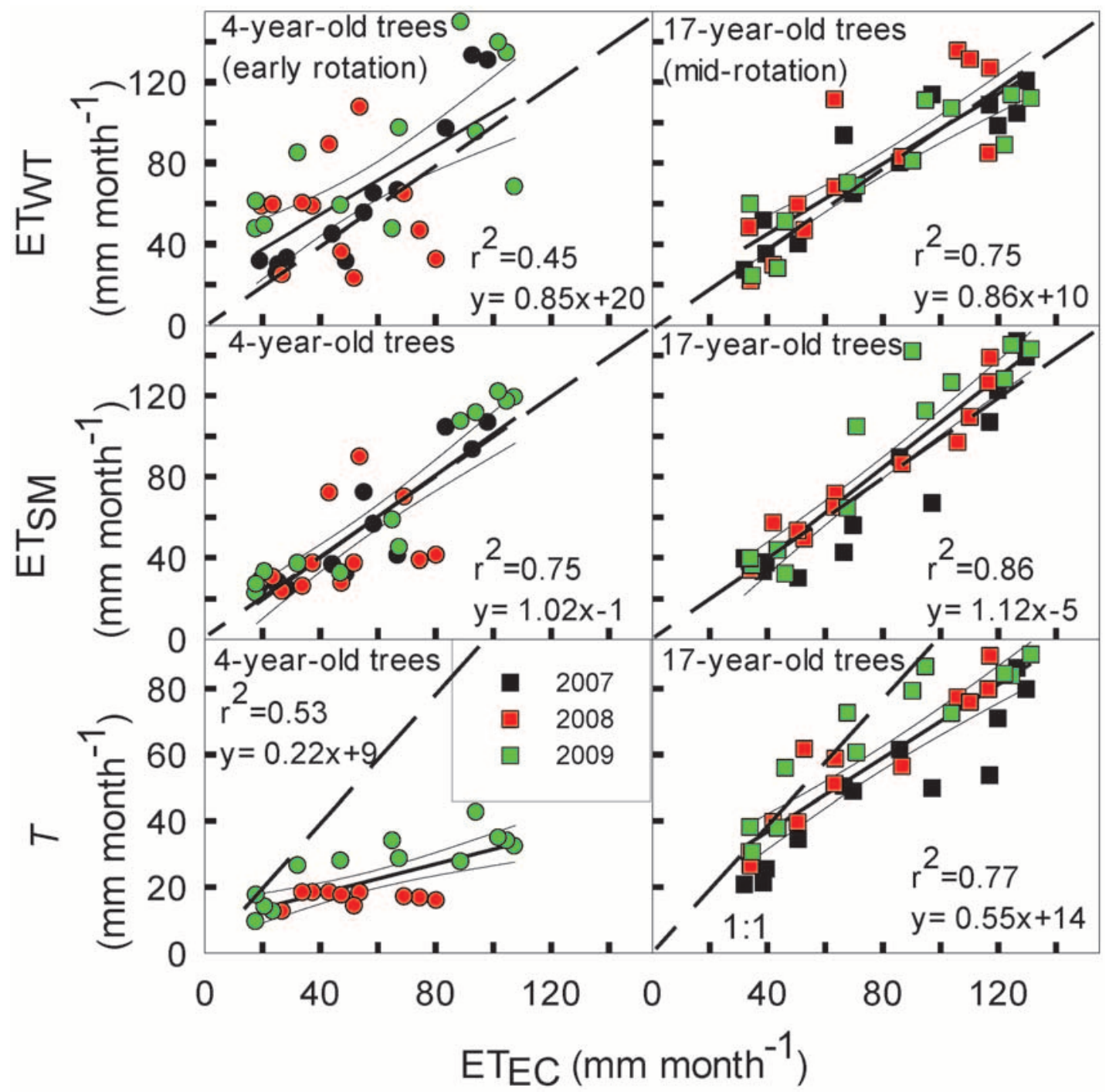

Figure 5. Monthly sum of water uptake in the water table $\left(\mathbf{E T}_{\mathrm{WT}}\right)$, soil water depletion of the entire soil profile $\left(\mathbf{E T}_{\mathrm{SM}}\right)$, and pine transpiration $(T)$ as a function of stand evapotranspiration (ET $\left.\mathrm{EC}\right)(\mathbf{9 5 \%}$ confidence intervals for the regressions are shown).

The low correlation between $\mathrm{ET}_{\mathrm{SM}}$ and $\mathrm{ET}_{\mathrm{EC}}$ for values lower than $2 \mathrm{~mm}$ day $^{-1}$ may be explained by the underestimation of $\mathrm{ET}_{\mathrm{EC}}$ on wet days because the sonic anemometer and infrared gas analyzer must be dry to function properly. After rain events, the sensors may thus underestimate evaporation of intercepted water as well as ecosystem transpiration (Stoy et al. 2006). Moreover, at the midrotation site, the tap root reached $1.9 \mathrm{~m}$ (Table 1), so we cannot reject the possibility of significant storage below the depth measured by our system (deepest sensor at $1.4 \mathrm{~m}$ ). In addition, the hysteresis observed on a daily basis between $\mathrm{ET}_{\mathrm{SM}}$ and $\mathrm{ET}_{\mathrm{EC}}$ values could be caused in part by transpiration of water stored in tree stems and branches (Phillips et al. 2003).

At both sites, values of $\mathrm{ET}_{\mathrm{wT}}$ were also in good agreement with those for $\mathrm{ET}_{\mathrm{EC}}$ on a monthly basis but not on a daily basis. At the mid-rotation site, $\mathrm{ET}_{\mathrm{WT}}$ underpredicted $\mathrm{ET}_{\mathrm{EC}}$ when soil water uptake was high, probably because soil water was also drawn directly from the saturated zone. The water table fluctuation method provided a point value of recharge computed from the water level rise in a well multiplied by the specific yield (i.e., drainable soil porosity) by assuming that a water level rise is caused by recharge entering at the water table (White 1932). Although simple in concept, this method has drawbacks in its application related to accurate estimation of specific yield and to the assumption that the specific yield between soil layers remains constant. Furthermore, for this study, the period from 01:00 to 04:00 was selected for the recovery analysis. However, the choice of this time period is somewhat subjective, and a different period may be better at other sites (Healy and Cook 2002). The optimal period for analysis may even shift and change in duration throughout the growing season within a site. If the plant has the ability to store a significant volume of water and the water status of the plant has been depleted during the day, uptake of water by the roots may continue for several hours after the plant has stopped transpiring (Phillips et al. 2003). Similarly, because hydraulic redistribution from deep roots is a significant process at these sites (Domec et al., 2010), root water uptake from the saturated zone may never be zero. Therefore, high rates of hydraulic redistribution could also explain the difference between $\mathrm{ET}_{\mathrm{WT}}$ and $\mathrm{ET}_{\mathrm{SM}}$ (Warren et al. 2007, 2011). For 

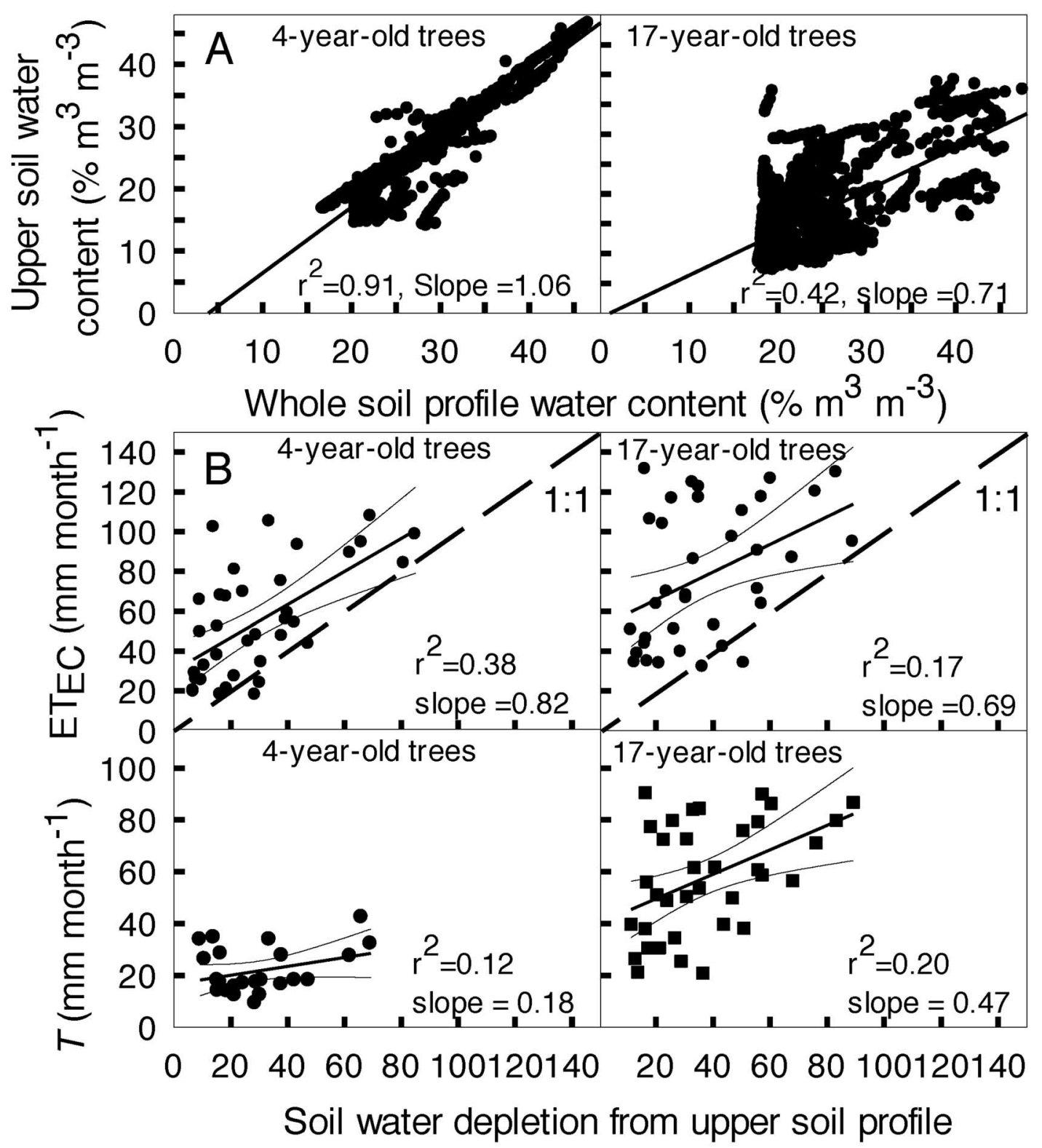

(ETSM, mm month ${ }^{-1}$ )

Figure 6. Daily mean of water content the upper soil layers as a function of soil water content of the entire soil profile (A), and monthly sum stand evapotranspiration $\left(\mathrm{ET}_{\mathrm{EC}}\right)$ and pine transpiration $(T)$ as a function of soil water depletion of the upper soil layers (B). In B, 95\% confidence intervals for the regressions are shown.

this reason, the hours immediately after sunset should not be used to determine the recovery rate ( $R$ in Equation 6). However, favorable aspects of this method include its simplicity and cost: it can be applied for any shallow well that taps the water table, and an abundance of available water level data exist, allowing spatial extrapolation.

\section{Contributions of Soil Water Storage to ET: Whole Profile Versus Upper Soil Layer}

At the mid-rotation site, soil moisture trends revealed the importance of measuring water content at several depths because less than $20 \%$ of the water is stored in the top $30 \mathrm{~cm}$ of soil. At this site, the discrepancy between $\theta$ measured throughout the whole soil profile and the upper soil profile there was due to the lower soil layers $(60-140 \mathrm{~cm})$ contributing a larger amount of water to daily water depletion relative to the upper layers $(10-60 \mathrm{~cm})$ when $\theta$ was low (Meiresonne et al. 2003, Warren et al. 2005, Domec et al. 2010). These results suggest that great care should be taken when one is comparing $T$ and $\mathrm{ET}_{\mathrm{EC}}$ to soil water dynamics measured from the upper soil profile even after correcting for root profile distribution (Miller et al. 2007). However, some of the differences in soil water storage measured throughout the whole soil profile and the upper soil profile are expected to be dampened by water hydraulically redistributed by deep roots (Warren et al. 2007). At the midrotation site, it has been recently shown that during the dry period approximately $80 \mathrm{~mm}$ of soil water could replenish the upper soil layers though this phenomenon (Domec et al. 2010). 

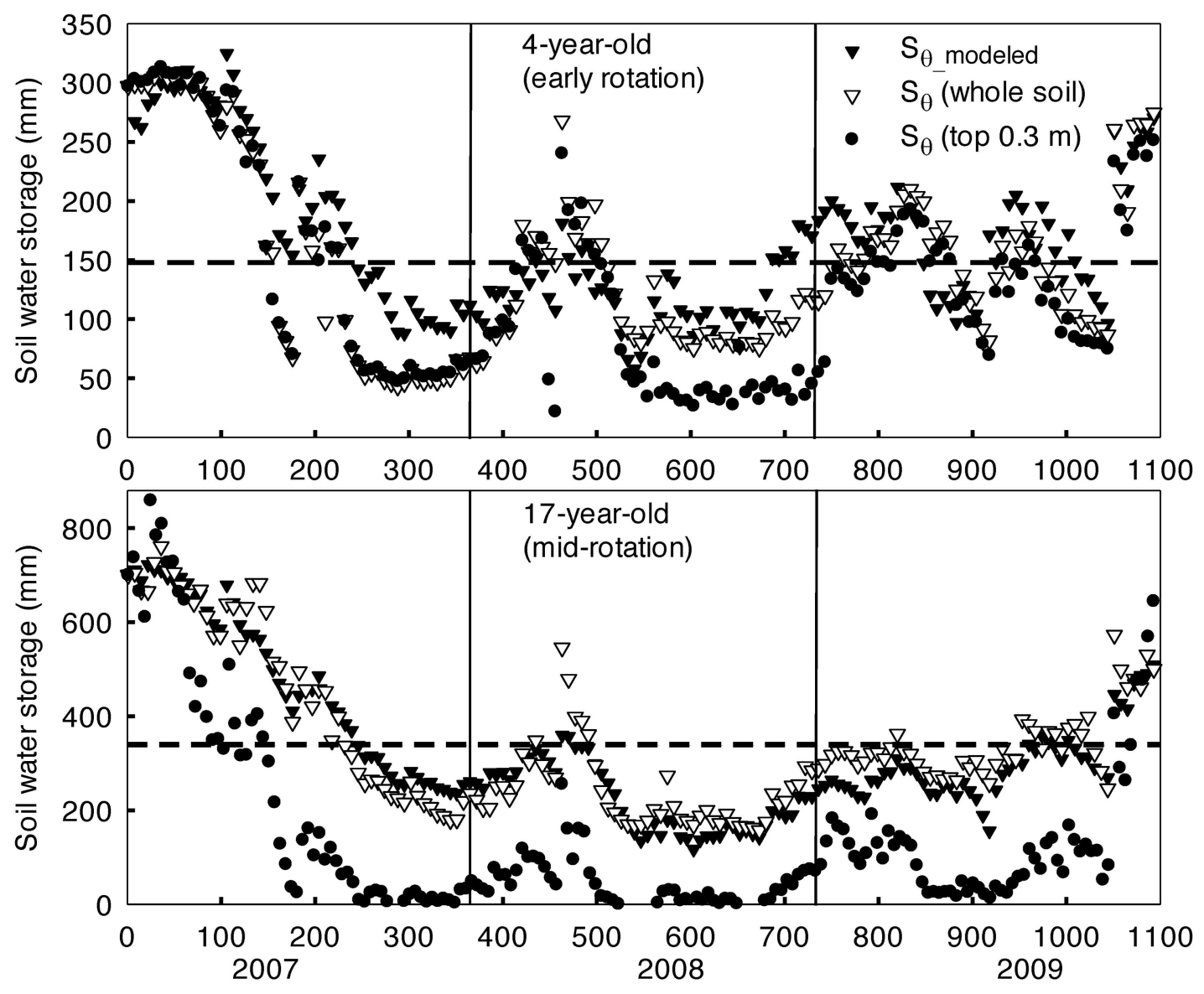

Figure 7. Weekly soil water storage in the top $1.9 \mathrm{~m}$ of soil for the mid-rotation site and in the top $0.8 \mathrm{~m}$ of soil for the early-rotation site based on scaled soil moisture probe values $\left(S_{\theta}\right)$ and modeled $\left(S_{\theta}\right.$ modeled $)$ as the residual of Equation 1 (i.e., precipitation minus $\mathbf{E}_{\mathrm{S}}+\mathrm{ET}_{\mathrm{EC}}+D$ ). The horizontal dashed lines delimit periods with relative extractable water $<50 \%$, which for these trees are supposed to induce water stress (Phillips and Oren 2001, Domec et al. 2009).

Great care should also be taken in the study of ecosystem responses to variation in soil $\theta$, such as soil respiration or soil water uptake, from measurements that rely on the upper soil profile only. Field and modeling studies relying on upper soil moisture to represent whole stand soil water dynamics would underestimate soil water depletion significantly during dry years and overestimate it during wet years. The threshold soil water storage corresponding to a relative extractable soil water of $40-50 \%$ was reached quickly in 2007 and stayed for more than a full year (Figure 2; Figure 7). This result indicates that the trees were under constant water stress in 2007 and 2008 and responded by closing their stomata to reduce $T$ (Phillips and Oren 2001, Domec et al. 2009). The threshold of $40-50 \%$ for relative extractable water, beyond which $T$ is reduced, has been previously reported in a large number of other tree species and soil types (Bréda et al. 2006, Vincke and Thiry 2008, Gonzalez-Benecke and Martin 2010).

\section{Partitioning the Effect of Soil Evaporation, Tree Transpiration, and Understory Vegetation on the Water Balance}

Canopy $I$ at the mid-rotation site, one of the two components of stand evaporation was low compared with that for other conifer plantations (Loustau et al. 1992), probably because rainfall events were of short duration but of high intensity (Crockford and Richardson 2000), characteristics of the southeastern United States. Our calculations indicated that $E_{S}$, the other component of stand evaporation that is often disregarded in forested ecosystems, was a major contributor to ET. Few studies estimate or measure $\mathrm{E}_{\mathrm{S}}$, and many assume that under a closed-canopy environment and thick forest floor, $\mathrm{E}_{\mathrm{S}}$ can be considered to be minimal because of poor coupling with the atmosphere and high resistance to water vapor loss from dry topsoil (Bréda et al. 2006). However, some reports (Benyon and Doody 2004, Oishi et al. 2008, 2010) also suggest that $E_{S}$ can contribute approximately $10-20 \%$ of total ET. The decrease in $E_{S}$ at the early-rotation site was attributed to an LAI-mediated decrease in soil temperature over the 3-year period, because stand peak LAI at this site increased from 3.3 in 2007 to 4.2 in 2009. In addition to decreasing the exposure of soil surface to incoming radiation, higher LAI also contributes to increased litter production, which may insulate the ground and suppress $\mathrm{E}_{\mathrm{S}}$ (Schaap and Bouten 1997, RazYaseef et al. 2010b).

Although the constant heat sap flux approach is often cited as underpredicting $T$ (Wilson et al. 2001, Bréda et al. 2006; Steppe et al. 2010), there was a good quantitative 
agreement between $T$ and $\mathrm{ET}_{\mathrm{EC}}$ during the winter when the overstory pine trees comprised almost $100 \%$ of total stand leaf area (Table 2). This was also probably due to the uniformity of the pine trees, reducing between-tree variability, and also because we measured sap flow across almost the entire sapwood depth, thus reducing within-tree uncertainties. Comparable in methodology to the present study, many studies have compared eddy covariance estimates of ET with sap flux scaled estimates of $T$. These studies generally used the difference in latent heat flux and scaled sap flux to partition evaporative fluxes. However, they did not validate sap flux scaled measurements of $T$ per se (Oren et al. 1998, Kurpius et al. 2003, McCulloh et al. 2007). In contrast, most studies assumed that $\mathrm{E}_{\mathrm{S}}$ and understory transpiration are negligible due to closed-canopy conditions, therefore assuming that $T$ is directly comparable with ET.

At the early-rotation site, loblolly pine LAI almost doubled between 2007 and 2009 and the growing season LAI of subdominant trees and understory vegetation doubled whole stand LAI (Table 1), explaining why understory transpiration represented up to $58 \%$ of total ET over a season (Table 3 ). Other studies have shown that understory vegetation can represent a considerable fraction of total LAI (Oren et al. 1987, Loustau and Cochard 1991, Baldocchi et al. 2000, Porté et al. 2009) and be the main driver of the increase in whole stand ET and thus carbon exchange after regeneration or until the stand reaches canopy closure (Jarosz et al. 2008, Domec et al. 2010). However, our comparison of methods to determine ET revealed that great care should be taken when using both soil water balance methods to estimate understory transpiration (Table 2).

As already reported for loblolly pine (Phillips and Oren 2001, Domec et al. 2009), $T$ is responsive to a decrease in $\theta$, with a decrease by more than $30 \%$ when relative extractable soil water drops to less than $50 \%$. However, although trees from both plantations were sensitive to drought as seen by the lower $T$ in 2007 and 2008, the mid-rotation stand exhibited little variation in annual ET (Table 2). This result has recently been observed in a forest composed of several tree species (Stoy et al. 2006, Oishi et al. 2010). Therefore, it is possible that on the early-rotation site, acclimation to high levels of water stress in 2007 and 2008 produced foliage with a conservative water use strategy. In a young plantation, chronic levels of water stress may affect the rate of water uptake even when water is available, reflecting a carryover effect of water availability on $T$ (Ewers et al. 1999).

\section{Conclusions}

The good agreement between the three methods at a monthly scale gives confidence in these approaches for estimating monthly and annual evapotranspiration. The water table fluctuation method does not require elaborate calibration or data processing, and recharge rates are values that are integrated over large areas and thus represent well the tower foot print. This is a distinct advantage relative to point measurement approaches such as the soil moisture probe methods. The choice of ET methods depends on project objectives and financial constraints. The eddy cova- riance method gives a high-resolution ET estimate for a homogeneous landscape; thus, it has the advantage for examining ecosystem processes when incorporating with simultaneous measurements of other gases (e.g., $\mathrm{CO}_{2}$ and $\mathrm{CH}_{4}$ ). However, this method is relatively costly compared with the other ET methods examined in this study. The soil water-based approach is less costly and provides a reasonable estimate of ET at a longer time scale (monthly) although it does not apply to daily ET estimates.

The early-rotation site was very sensitive to summer drought as opposed to the mid-rotation site. At the mid-rotation site, soil moisture trends demonstrated the importance of measuring water content at several depths throughout the rooting zone. Combining measurements of sapflow, soil evaporation, and canopy interception provided insights to the response of water use by plants to climatic variability and stand development. Tree transpiration and evapotranspiration were not directly comparable because understory and soil transpiration rates were not negligible. Pine transpiration showed remarkable consistency as the stands developed, regardless of the accompanying increases in LAI and changes in understory composition from early- to midrotation. At the early-rotation site, this conservation of water use was achieved through relatively low transpiration rates (compared with PET and ET) and compensatory transpiration among the overstory trees and understory vegetation. At this site, reduced water availability will affect trees more than understory or soil, whereas at the mid-rotation site, it would affect more understory transpiration, which might be conducive for management efforts.

\section{Literature Cited}

AmATYA, D.M., AND R.W. SKAGGS. 2001. Hydrologic modeling of pine plantations on poorly drained soils. For. Sci. 47:103-114.

BALDOCCHI, D.D., B.E. LAW, AND P.M. ANTHONI. 2000. On measuring and modeling energy fluxes above the floor of a homogeneous and heterogeneous conifer forest. Agric. For. Meteorol. 102:187-206.

BALDOCCHI, D.D., L.K. Xu, AND N. KIANG. 2004. How plant functional-type, weather, seasonal drought, and soil physical properties alter water and energy fluxes of an oak-grass savanna and an annual grassland. Agric. For. Meteorol. 123: 13-39.

BARBIER, S., P. BALANDiER, AND F. Gosselin. 2009. Influence of several tree traits on rainfall partitioning in temperate and boreal forests: A review. Ann. For. Sci. 66:1-11.

BARnARD, H.R., C.B. Graham, W.J. VAN Verseveld, J.R. BROOKS, B.J. Bond, AND J.J. MCDONNELL. 2010. Mechanistic assessment of hillslope transpiration controls of diel subsurface flow: A steady-state irrigation approach. Ecohydrology 3:133-142.

BENYON, R.G., AND T.M. DoODY. 2004. Water use by tree plantations in South East South Australia, Report 148. CSIRO Forestry, Forest Products, Mount Gambier. 26 p.

Bond, B.J., J.R. BRoOKs, AND F.C. MeInZER. 2008. How trees influence the hydrological cycle in forest ecosystems, in $\mathrm{Hy}$ droecology and ecohydrology: Past, present and future, Wood, P.J., D.M. Hannah, and J.P. Sadler (eds.). John Wiley \& Sons, New York.

BrédA, N., R. Huc, A. Granier, AND E. Dreyer. 2006. Temperate forest trees and stands under severe drought: A review of 
ecophysiological responses, adaptation processes and longterm consequences. Ann. For. Sci. 63:625-644.

Brooks, J.R., F.C. Meinzer, R. Coulombe, And J. GregG. 2002. Hydraulic redistribution of soil water during summer drought in two contrasting Pacific Northwest coniferous forests. Tree Physiol. 22:1107-1117.

Burba, G.G., D.K. McDermitt, A. Grelle, D.J. Anderson, And L. XU. 2008. Addressing the influence of instrument surface heat exchange on the measurements of $\mathrm{CO}_{2}$ flux from openpath gas analyzers. Global Change Biol. 14:1854-1876.

CAmpBell, R.G., AND J.H. Hughes. 1991. Impacts of forestry operations on pocosins and associated wetlands. Wetlands 11:467-479.

CrockFord, R.H., AND D.P. RichARDSON. 2000. Partitioning of rainfall into throughfall, stemflow and interception: Effects of forest type, ground cover and climate. Hydrol. Processes 14:2903-2920.

DigGS, J.A. 2004. Simulation of nitrogen and hydrology loading of forested fields in Eastern North Carolina using DRAINMOD- $N$ 11. M.Sc. thesis, North Carolina State Univ., Raleigh, NC. $155 \mathrm{p}$.

Domec, J.-C., J.S. King, A. NoORmets, G. Sun, S.G. McNulty, M. GAVAZZI, AND E. TREASURE. 2010. Hydraulic redistribution of soil water by roots affects whole stand evapotranspiration and net ecosystem carbon exchange. New Phytol. 187:171-183.

Domec, J.-C., A. Noormets, J.S. King, G. Sun, S.G. McNulty, M. Gavazzi, J. Boggs, And E. Treasure. 2009. Decoupling the influence of leaf and root hydraulic conductances on stomatal conductance and its sensitivity to vapor pressure deficit as soil dries in a drained loblolly pine plantation. Plant Cell Environ. 32:980-991.

Ewers, B.E., R. Oren, T.J. Albaugh, And P.M. Dougherty. 1999. Carry-over effects of water and nutrient supply on water use of Pinus taeda. Ecol. Appl. 9:513-525.

Ford, C.R., C.E. GORANSON, R.J. MitChELL, R.E. WILl, AND R.O. TESKEY. 2005. Modeling canopy transpiration using time series analysis: A case study illustrating the effect of soil moisture deficit on Pinus taeda. Agric. For. Meteorol. 130:163-175.

Ford, C.R., R.M. Hubbard, B.D. KloepPel, AND J. Vose. 2007. A comparison of sap flux-based evapotranspiration estimates with catchment-scale water balance. Agric. For. Meteorol. 145:176-185.

Gibbard, S., K. Caldeira, G. Bala, T.J. Phillips, and M. WiCKETT. 2005. Climate effects of global land cover change. Geog. Res. Lett. 32:L23705.

Gholz, H.L., AND K.L. ClarK. 2002. Energy exchange across a chronosequence of slash pine forests in Florida. Agric. For. Meteorol. 112:87-102.

GonZALEZ-Benecke, C.A., AND T.A. MARTin. 2010. Water availability and genetic effects on water relations of loblolly pine (Pinus taeda L.) stands. Tree Physiol. 30:376-392.

Grace, M.J. III, R.W. Skaggs, And D.K. Cassel. 2006. Soil physical changes associated with forest harvesting operations on an organic soil. Soil Sci. Soc. Am. J. 70:503-509.

GRANIER, A. 1987. Evaluation of transpiration in a Douglas-fir stand by means of sap flow measurements. Tree Physiol. 3:309-320.

HANSON, P.J., AND J.F. WELTZIN. 2000. Drought disturbance from climate change: Response of United States forests. Sci. Total Environ. 262:205-220.

Healy, R., AND P. CoOK. 2002. Using groundwater levels to estimate recharge. Hydrogeol. J. 10:91-109.

HILL, A.J., AND V.S. NEARY. 2007. Estimating evapotranspiration and seepage for a sinkhole wetland from diurnal surface-water cycles. J. Am. Water Resourc. Assoc. 43:1373-1382.
Irvine, J., B.E. LAw, M.R. Kurpius, P.M. Anthoni, D. Moore, AND P. SChwarZ. 2004. Age related changes in ecosystem structure and function and the effects on water and carbon exchange in ponderosa pine. Tree Physiol. 24:753-763.

Jarosz, N., Y. BRUnEt, E. LAMAUd, M. IRVInE, J.M. BonNEFOND, AND D. Loustau. 2008. Carbon dioxide and energy flux partitioning between the understorey and the overstorey of a maritime pine forest during a year with reduced soil water availability. Agric. For. Meteorol. 148:1508-1523.

Kelting, D.L., J.A. Burger, AND S.C. PAtTerson. 2000. Early loblolly pine growth response to changes in the soil environment. N.Z. J. For. Sci. 30:206-224.

KNyAZIKHIN, Y., J.V. MaRTONCHIK, R.B. Myeni, D.J. DineR, AND S.W. RUNNING. 1998. Synergistic algorithm for estimating vegetation canopy leaf area index and fraction of absorbed photosynthetically active radiation from MODIS and MISR data. J. Geophys. Res. 103:32257-32274.

KurPius, M.R., J.A. PANEK, N.T. NikOlov, M. McKay, AND A.H. GoLDSTEIN. 2003. Partitioning of water flux in a Sierra Nevada ponderosa pine plantation. Agric. For. Meteorol. 117:173-192.

LAI, C.T., AND G. KATUl. 2000. The dynamic role of root-water uptake. J. Hydrometeorol. 530:427-439.

Law, B.E., T. Arkebauer, J.L. Campbell, J. Chen, O. Sun, M. SCHWARTZ, AND C. VANIngen. 2009. Terrestrial carbon observations: Protocols for vegetation sampling and data submission. Report 55, Global Terrestrial Observing System. Food and Agriculture Organization, Rome, Italy. 87 p.

LOHEIDE, S.P. 2008. A method for estimating subdaily evapotranspiration of shallow groundwater using diurnal water table fluctuations. Ecohydrology 1:59-66.

Loustau, D., P. Berbigier, A. Granier, And F.E. Moussa. 1992. Interception loss, throughfall and stemflow in a maritime pine stand. I. Variability of throughfall and stemflow beneath the pine canopy. J. Hydrol. 138:449-467.

Loustau, D., AND H. COChARD. 1991. Utilisation d'une chambre de transpiration portable pour l'estimation de l'évapotranspiration d'un sous-bois de Pin maritime á Molinie (Molinia coerulea (L.) Moench.). Ann. Sci. For. 48:29-45.

MARTin, T.A. 2000. Winter season tree sap flow and stand transpiration in an intensively-managed loblolly and slash pine plantation, J. Sustain. For. 10:155-163.

Meiresonne, L., D.A. SAmpson, A.S. Kowalski, I.A. Janssens, N. Nadezhdina, J. Cermak, J. Van Slycken, and R. CeuleMANS. 2003. Water flux estimates from a Belgian Scots pine stand: A comparison of different approaches. J. Hydrol. 270:230-252.

MCCARThy, E.J., R.W. SkagGS, AND P. FARNum. 1991. Experimental determination of the hydrologic components of a drained forest watershed. Trans. ASAE 34:2031-2039.

McCulloh, K.A., K. Winter, F.C. Meinzer, M. Garcia, J. ARANDA, AND B. LACHENBRUCH. 2007. A comparison of daily water use estimates derived from constant-heat sap-flow probe values and gravimetric measurements in pot-grown saplings. Tree Physiol. 27:1355-1360.

McDowell, N.G., S. White, And W.T. Pockman. 2008. Transpiration and stomatal conductance across a steep climate gradient in the southern Rocky Mountains. Ecohydrology 1:193-204.

McKeand, S., T. Mullin, T. Byram, And T. White. 2003, Deployment of genetically improved loblolly and slash pine in the South. J. For. 101:32-37.

Miller, G.R., D.D. BALDOCCHI, B.E. LAW, AND T. MEYers. 2007. An analysis of soil moisture dynamics using multi-year data from a network of micrometeorological observation sites. Adv. Water Resourc. 30:1065-1081. 
Moore, G.W., B.J. Bond, J.A. Jones, N. Phillips, And F.C. MEINZER. 2004. Structural and compositional controls on transpiration in 40-and 450-year-old riparian forests in western Oregon USA. Tree Physiol. 24:481-491.

Noormets, A., M. Gavazzi, S.G. McNulty, G. Sun, J.-C. Domec, J.S. King, AND J. CHEN. 2010. Response of carbon fluxes to drought in a coastal plain loblolly pine forest. Global Change Biol. 16:272-287.

Noormets, A., S.G. McNulty, J.L. DeForest, G. Sun, Q. Li, AND J. CHEN. 2008. Drought during canopy development has lasting effect on annual carbon balance in a deciduous temperate forest. New Phytol. 179:818-828.

OAK Ridge National Laboratory Distributed Active ARCHIVE CENTER. 2010. MODIS subsetted land products, collection 5. Oak Ridge, TN. Available on-line at daac.ornl.gov/ MODIS/modis.html; last accessed May 20, 2010.

Oishi, A.C., R. Oren, K. Novick, S. Palmroth, And G.G. KATUL. 2010. Interannual invariability of forest evapotranspiration and its consequence to water flow downstream. Ecosystems 13:421-436.

Oishi, A.C., R. ORen, AND P.C. Stoy. 2008. Estimating components of forest evapotranspiration: A footprint approach for scaling sap flux measurements. Agric. Forest Meteorol. 148:719-732.

Oren, R., N. Phillips, G. Katul, B.E. Ewers, And D.E. PATAKi. 1998. Scaling xylem sap flux and soil water balance and calculating variance: A method for partitioning water flux in forests. Ann. Sci. For. 55:191-216.

OREN, R., R.H. WARING, S.G. STAFFORD, AND J.W. BARRETT. 1987. Twenty-four years of ponderosa pine growth in relation to canopy leaf area and understory competition. For. Sci. 33:538-547.

Palmroth, S., G.G. Katul, H. Dafeng, H.R. McCarthy, R.B. JACKSON, AND R. OREN. 2010. Estimation of long-term basin scale evapotranspiration from streamflow time series. Water Resourc. Res. 46:W10512; doi: 10.1029/2009WR008838.

PHILLIPS, N., AND R. OREN. 2001. Intra- and inter-annual variation in transpiration of a pine forest. Ecol. Appl. 11:385-396.

Phillips, N.G., M.G. Ryan, B.J. Bond, N.G. McDowell, T.M. Hinkley, AND J. CERMAK. 2003. Reliance on stored water increases with tree size in three species in the Pacific Northwest, Tree Physiol. 23:237-245.

Porté, A.J., J.-C. Samalens, R. Dulhoste, R. Teissier Du Cros, A. Bosc, AND C. MeredieU. 2009. Using cover measurements to estimate aboveground understorey biomass in Maritime pine stands. Ann. Sci. For. 66:307; doi: 10.1051/forest/2009005.

Powell, T.L., H.L. Gholz, K.L. Clark, G. Starr, W.P. CropPER, AND T.A. MARTIN. 2008. Carbon exchange of a mature, naturally regenerated pine forest in north Florida. Global Change Biol. 14:2523-2538.

RAZ-YASEEF, N., E. RoTENBERG, AND D. YAKIR. 2010a. Effects of spatial variations in soil evaporation caused by tree shading on water flux partitioning in a semi-arid pine forest. Agric. For. Meteorol. 150:454-462.

RAZ-YAseef, N., D. YAKIR, E. RotenBerG, G. SChiller, AND S. COHEN. 2010b. Ecohydrology of a semi-arid forest: Partitioning among water balance components and its implications. Ecohydrology 3:143-154.

SCHAAP, M.G., AND W. BouTEN. 1997. Forest floor evaporation in a dense Douglas fir stand. J. Hydrol. 193:97-113.

Schwarzel, K., A. Menzer, F. Clausnitzer, U. Spnak, J. Hantzschel, T. Grunwald, B. Kostner, C. Bernhofer, AND K. FEGER. 2009. Soil water content measurements deliver reliable estimates of water fluxes: A comparative study in a beech and a spruce stand in the Tharandt forest (Saxony, Germany). Agric. For. Meteorol. 149:1994-2006.
SPerry J.S., F.R. Adler, G.S. CAMPBell, AND J.P. COMSTOCK. 1998. Limitation of plant water use by rhizosphere and xylem conductance: Results from a model. Plant Cell Environ. 21:3 47-359.

Steppe, K., D.J.E. DePauw, T.M. Doody, and R.O. Teskey. 2010. A comparison of sap flux density using thermal dissipation, heat pulse velocity and heat field deformation methods. Agric. For. Meteorol. 150:1046-1056.

Stogsdill, W.R., R.F. Wittwer, T.C. Hennessey, and P.M. DOUGHERTY. 1989. Relationship between throughfall and stand density in a Pinus taeda plantation. For. Ecol. Manage. 29:105-133.

Stoy, P.C., G.G. Katul, M.B.S. Siqueira, J.-Y. JuAnG, K.A. NOVICK, H.R. MCCARTHY, A.C. OISHI, J.M. UEBELHERR, H.-S. KIM, AND R. OREN. 2006. Separating the effects of climate and vegetation on evapotranspiration along a successional chronosequence in the southeastern US. Global Change Biol. 12:2115-2135.

Sun, G., D.M. Amatya, S.G. McNulty, R.W. SkaggS, And J.H. HUGHES. 2000. Climate change impacts on the hydrology and productivity of a pine plantation. J. Am. Water Resourc. Assoc. 36:367-374.

Sun, G., S.G. McNulty, D.M. Amatya, R.W. Skaggs, L.W. SwIFT, J.P. SHEPARD, AND H. RIEKERK. 2002. A comparison of the hydrology of the coastal forested wetlands/pine flatwoods and the mountainous uplands in the southern US. J. Hydrol. 263:92-104.

Sun, G., A. Noormets, M.J. Gavazzi, S.G. McNulty, J. Chen, J.-C. Domec, J. King, D.M. Amatya, And R.W. SkagGS. 2010. Energy and water balance of two contrasting loblolly pine plantations on the lower coastal plain of North Carolina, USA. For. Ecol. Manage. 259:1299-1310.

Synclair, T.R., AND K.R. KNOERR. 1982. Distribution of photosynthetically active radiation in the canopy of a loblolly pine plantation. J. Appl. Ecol. 19:183-191.

VINCKE, C., AND Y. THIRY. 2008. Water table is a relevant source for water uptake by a Scots pine (Pinus sylvestris L.) stand: Evidences from continuous evapotranspiration and water table monitoring. Agric. Forest Meteorol. 148:1419-1432.

Warren, J.M., F.C. Meinzer, J.R. Brooks, And J.-C. DomeC. 2005. Vertical stratification of soil water storage and release dynamics in Pacific Northwest coniferous forests. Agric. For. Meteorol. 130:39-58.

WARren, J.M., F.C. MeInZER, J.R. BRoOKS, J.-C. DomeC, AND R. Coulombe. 2007. Hydraulic redistribution of soil water in two old-growth coniferous forests: Quantifying patterns and controls. New Phytol. 173:753-765.

Warren, J.M., F.C. Meinzer, J.R. Brooks, AND M.I. Draglia. 2011. In situ separation of root hydraulic redistribution of soil water from liquid and vapor transport. Oecologia 166:899-911.

WHITE, W. 1932. A method for estimating ground-water supplies based on discharge by plants and evaporation from soil. US Geol. Surv. Water Supply Paper 659-A. US Government Printing Office, Washington, DC.

Williams D.G., W. Cable, K. Hultine, J.C.B. Hoedjes, E.A. Yepez, V. Simonneaux, S. ER-RaKi, G. Boulet, H.A.R. DE Bruin, A. Chehbouni, O.K. Hartogensis, and F. Timouk. 2004. Evapotranspiration components determined by stable isotope, sap flow and eddy covariance techniques. Agric. For. Meteorol. 125:241-258.

Wilson, K.B., P.J. Hanson, P.J. Mulholland, D.D. BaldoCChi, AND S.D. WULLSCHLEGER. 2001. A comparison of methods for determining forest evapotranspiration and its components: Sapflow, soil water budget, eddy covariance and catchment water balance. Agric. For. Meteorol. 106:153-168. 